\title{
АХУНОВО-ПЕТРОПАВЛОВСКИЙ ГРАНИТОИДНЫЙ АРЕАЛ КАК ОКРАИННО- КОНТИНЕНТАЛЬНЫЙ ЦЕНТР ДЛИТЕЛЬНОГО МАНТИЙНО-КОРОВОГО ВЗАИМОДЕЙСТВИЯ: РОЛЬ СУБДУКЦИОННЫХ И РИФТОГЕННО-ПЛЮМОВЫХ ИСТОЧНИКОВ
}

\author{
В.В. Холоднов ${ }^{1}$, Е.С. Шагалов ${ }^{1,2}$, Г.А. Каллистов ${ }^{1}$, Г.Ю. Шардакова ${ }^{1,2}$, \\ Д.Н. Салихов ${ }^{3}$, Е.В. Коновалова ${ }^{1}$ \\ ${ }^{1}$ ФББУН Институт геологии и геохимии им. академика А.Н. Заварицкого Уральского \\ отделения Российской академии наук, e-mail: holodnov@igg.uran.ru \\ 620016 Российская Федерация, Екатеринбург, ул. Академика Вонсовского, 15 \\ ${ }^{2}$ ФББОУ ВО Уральский государственный горный университет, \\ 620144, Екатеринбург, ул. Куйбышева, д.30 \\ ${ }^{3}$ Институт геологии - обособленное структурное подразделение ФГБНУ Уфимского \\ федерального исследовательского центра Российской академии наук (ИГ УФИЦ РАН), \\ 450077 Российская Федерация, Республика Башкортостан, Уфа, ул. Карла Маркса, 16/2 \\ e-mail:magm@ufaras.ru
}

Ахуново-Петропавловский ареал позднепалеозойского гранитоидного магматизма расположен в северо-восточной части Магнитогорской мегазоны (ММ3) Южного Урала. Он представляет собой ряд последовательно внедряющихся интрузий (Петропавловской, Ахуновской, Карагайской и Уйскоборской), которые различаются не только особенностями состава, глубиной формирования и рудоносностью, но и связью с различными магматическими и флюидными источниками, а также механизмами магмогенерации. По набору магматических комплексов данный ареал существенно отличается от проявлений интрузивного магматизма и рудогенеза в центральной и западной частях зоны.

Во времени импульсы гранитоидного магматизма чередовались с этапами коллизионных сдвиго-раздвиговых деформаций и рифтогенного растяжения. На раннем этапе эволюции ареала произошло становление мезоабиссального Петропавловского

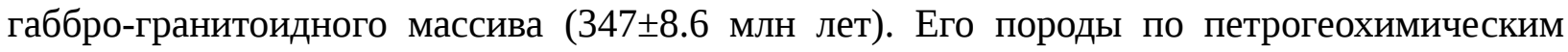
признакам наиболее близки к надсубдукционным образованиям - продуктам плавления мантийного субстрата, обогащенного не только водным флюидом, но и хлором. Далее, в диапазоне 310-306 млн. лет, на этапе коллизионного сжатия внедрялись коровые интрузии ахуново-карагайского гранодиорит-гранитного комплекса, по составу близкие к окраинноконтинентальным габбро-тоналит-гранодиорит-гранитным (ГТТГ) батолитам Среднего Урала, имеющим возраст 320-290 млн. лет и специализированным на крупное золотосульфидно-кварцевое оруденение (Березовское месторождение и др.). На завершающем этапе эволюции ареала, в эпоху перехода от окраинно-континентального режима к жесткой коллизии между Восточно-Европейским и Казахстанским континентами (конец карбона), при усилении сдвиго-раздвиговых деформаций образовался Уйскоборский граносиенит-гранитный массив $(304 \pm 4,8$ млн. лет), богатый калием и высокозарядными элементами. Подобный тип гранитоидных интрузий в ММЗ выделен впервые.

Таким образом, в Ахуново-Петропавловском ареале в условиях смены геодинамических обстановок сформировались гранитоидные комплексы, имеющие разный состав, глубинность и генезис. Это позволяет рассматривать данный ареал как типичный окраинно-континентальный центр длительного мантийно-корового взаимодействия, где 
процессы магмообразования происходили на разных уровнях мантии и коры, с участием как надсубдукционных, так и обогащенных плюм-зависимых рифтогенных источников.

Ключевые слова: гранитообразование, субдукция, коллизия, рифтогенез, плюмлитосферное и мантийно-коровое взаимодействие, режим флюидов, рудоносность

\title{
AKHUNOVO-PETROPAVLOVSKY GRANITOID AREA AS A MARGINAL CONTINENTAL CENTER OF THE LONG-TERM MANTLE-CRUST INTERACTION: THE SIGNIFICANCE OF SUBDUCTION AND RIFTOGENIC-PLUME SOURCES
}

\author{
V.V. Kholodnov', E.S. Shagalov ${ }^{1,2}$, G.A. Callistov', G. Yu. Shardakova ${ }^{1,2}$, \\ D.N. Salikhov ${ }^{2}$, E.V. Konovalova ${ }^{1}$ \\ ${ }^{1}$ Institute of Geology and Geochemistry named after Academician A.N. Zavaritsky, Ural Branch \\ of the Russian Academy of Sciences (IGG UB RAS), e-mail: holodnov@igg.uran.ru \\ 620016 Russian Federation, Ekaterinburg, Academika Vonsovskogo str., 15 \\ ${ }^{2}$ Ural State Mining University \\ 620144, Russian Federation, Ekaterinburg, Kuibyshev str., 30 \\ ${ }^{3}$ Institute of Geology, Ufa Federal Research Center of the Russian Academy of Sciences (IG \\ UFIC RAS), \\ 450077 Russian Federation, Republic of Bashkortostan, Ufa, ul. Karl Marks str., 16/2 \\ e-mail:magm@ufaras.ru
}

The Akhunovo-Petropavlovsky area of the Late Paleozoic granite magmatism is located in the north-eastern part of the Magnitogorsk megazone (MMZ) on the Southern Urals. There is the row of consistently implemented intrusions (the Petropavlovsk, Akhunovsk, Karagay and Uiskoborsk), which are differ not only in composition, depth of formation, ore-bearing capacity but in source compound (magmatic and fluid) and way of magma generation. This area differs significantly from the magmatic rocks and ore formations from the central and western parts of the zone in number and composition of intrusive complexes.

In time impulses of granite magmatism alternated with stages of collisional shearingspreading and rifting. The Petropavlovsk mesoabissal granite massif $(347 \pm 8.6 \mathrm{Ma})$ was formed at an early stage of area evolution and rocks are similar in composition to suprasubduction series of the Uralian orogen (products of melting of the mantle substrate enriched not only in water fluid, but also in $\mathrm{Cl}$ ). Then (310-306 Ma) the stage of collision compression took place and ctustal intrusions of Akhunovo-Karagay granodiorite-granite complex were generated. They are very similar to continental marginal gabbro-tonalite-granodiorite-granite plutons having the ages 320-290 Ma and bearing large gold-sulfide-quartz deposits (Berezovsk et al). At the final stage of area evolution, during transition from continental margin regime to hard collision, when the shear-spreading deformations were forced, the Uiskoborsk granosyenite-granite massif was formed. It is enriched in K and HFSE and such type was selected in MMZ for the first time.

Thereby, granitoid complexes of the Akhunovo-Petropavlovsky area were generated in conditions of geodynamic environment change and have different composition, depth and genesis. This allows considering this area as a typical marginal continental center of long-term 
mantle-crustal interaction, where magma generation occurred at different levels of mantle and crust, with the participation of both suprasubduction and enriched plume-dependent rift sources.

Keywords: plume-lithosphere and mantle-crustal interaction, granite generation, subduction, collision, rifting, fluid regime, potential ore bearing

\section{ВВЕДЕНИЕ}

Магнитогорская мегазона (ММ3) представляет собой реликт одной из палеозойских островных дуг Южного Урала, хорошо сохранившихся при коллизионных процессах. Энсиматическая Магнитогорская островная дуга (МОД) заложилась в начале девона, а в позднем девоне достигла стадии зрелой дуги. Она имеет офиолитовое основание, в фундаменте отсутствуют древние сиалические блоки [Серавкин и др., 2001; Ферштатер, 2013]. В конце девона произошла коллизия МОД с пассивной окраиной ВосточноЕвропейского континента (ВЕК). След зоны сочленения - Главный Уральский разлом (ГУР). Причленение МОД привело к расширению ВЕК на восток в область современного Тургайского прогиба и Валерьяновской зоны. Перескок зоны субдукции на восток и смена ее полярности с восточной на западную [Сурин, Мосейчук, 1995, 1999; Мизенс, 2002; Пучков, 2010 и др.] определили формирование (поздний девон-карбон) активной континентальной окраины (АКО).

В раннем карбоне произошло заклинивание новообразованной зоны субдукции. Отрыв слэба и его свободное погружение в мантию привели к исчезновению преграды, в виде субдуцируемой коры, между литосферой и астеносферой [Пучков, 2018, Салихов и др., 2019а, 2019б]. Это способствовало более свободному подъему мантийных диапировплюмов и началу их взаимодействия с постостроводужной литосферой, возникновению очагов плавления на разных глубинных уровнях мантии и в низах коры. Продукты такого взаимодействия в различной степени испытали влияние надсубдукционного флюида, смешение магм, а также контаминацию их веществом коры.

Процессы плюм-литосферного взаимодействия в ММЗ исследуются особенно интенсивно на примере магматических комплексов центральной и западной структурноформационных зон [Салихов и др., 2014, 2016, 2019]. Выделены внутриплитные серии плюмовой природы, несмотря на присутствие у них ряда неплюмовых (субдукционных и др.) признаков.

В северо-восточной части ММЗ магматические образования исследованы в меньшей степени. Здесь в позднем палеозое были сформированы два крупных гранитоидных ареала: Ахуново-Петропавловский - на севере и ВерхнеуральскоКассельский - южнее. В составе этих ареалов наряду с производными мантийных магм (Петропавловский, Кассельский габбро-гранитоидные массивы) появляются крупные гранитные массивы (Ахуновский, Карагайский, Заматохинский), связанные с процессами надсубдукционного анатексиса [Холоднов и др., 2009, 2013, 2017a], а также Уйскоборский граносиенит-гранитный массив, генезис которого не вполне ясен.

Данная работа представляет собой результаты более детального изучения гранитоидов Ахуново-Петропавловского ареала. Задачи исследования: 1) на основе новых аналитических данных уточнить петрологическую и геодинамическую типизацию гранитоидных комплексов этого ареала, 2) провести их сопоставление с особенностями продуктов внутриплитного плюм-зависимого и надсубдукционного магматизма из других 
структурно-формационных зон МM3, 3) определить РТ-условия становления последовательно формирующихся интрузий в данном ареале и охарактеризовать особенности их флюидного режима и рудоносности, 4) дать обобщающую характеристику Ахуново-Петропавловского ареала как центра длительного мантийнокорового взаимодействия на активной окраине-континента, оценить вклад субдукционных и рифтогенно-плюмовых источников в процессы магмогенерации.

Изучение процессов мантийно-корового и плюм-литосферного взаимодействия на постостроводужном этапе эволюции ММЗ имеет большой общенаучный и практический смысл, поскольку к этой зоне приурочены многочисленные рудные месторождения (скарново-магнетитовые и титаномагнетитовые, золоторудные и золото-вольфрамовые и др.), связанные с позднепалеозойскими магматическими комплексами разного состава и природы.

\section{МЕТОДЫ ИССЛЕДОВАНИЯ}

Основные виды аналитических исследований выполнены в ЦКП « Геоаналитик » Института геологии и геохимии УрО РАН, г. Екатеринбург. Изучение химического состава горных пород проведено рентгенфлюоресцентным методом на СРМ-35. Концентрации микроэлементов определялись с помощью масс-спектрометров с индуктивно-связанной плазмой ELAN-9000 и NexION 300 (PerkinElmer). Погрешности определения не превышают 10 отн. \%. Подготовка проб для анализа проводится с использованием сверхчистых реактивов: для воды используется система очистки фирмы Millipore, с удельным сопротивлением готовой воды 18.2 Мом/см; используемые для пробоподготовки и проведения анализа реактивы квалификации ОСЧ дополнительно очищаются методом «недокипящей» дистилляции в системе перегонки кислот BSB-939-IR фирмы Berghof. Работа проводится с использованием кварцевой, фторопластовой и полипропиленовой посуды. Для разложения проб используются СВЧ-печи ПЛП-01 фирмы Урал-Гефест, система микроволнового разложения Speedway MWS-3+ фирмы Berghoff и автоклавный модуль МКП-05 фирмы Анкон-АТ. Все аналитические работы проводятся в комплексе чистых помещений, который выполнен по принципу «комната в комнате». Реализованные в комплексе чистых помещений технические решения обеспечивают чистоту в помещениях класса 7 и 8 ИСО по ГОСТ 146444-1-2002. Изучение состава породообразующих минералов проведено в полированных шлифах на волновом рентгеновском микроанализаторе CAMECA SX-100.

\section{ГЕОЛОГИЧЕСКАЯ ПОЗИЦИЯ, СОСТАВ СЕРИЙ И УСЛОВИЯ ФОРМИРОВАНИЯ ГРАНИТОИДНЫХ ИНТРУЗИЙ АХУНОВО - ПЕТРОПАВЛОВСКОГО ГРАНИТОИДНОГО АРЕАЛА}

Ахуново-Петропавловский ареал гранитоидного магматизма находится в северной части Восточно-Магнитогорской зоны (BM3) — в Гумбейской подзоне. Он имеет компактное строение (рис. 1) и состоит из сближенных в пространстве, но разновозрастных и различающихся по составу серий и условиям формирования интрузий: Петропавловской (на рис. 1б, цифра 8), Ахуновской (9), Карагайской (10), Уйскоборской (7) и Воронинской (6). Два других центра позднепалеозойского гранитоидного магматизма северной части ММЗ - Верхнеуральско-Кассельский (на рис. $1 б$ - массивы 11-16) и Сыростанско-Тургоякский (1) ареалы. Последний находится в зоне сочленения ММЗ с краем ВЕК (запад зоны ГУР). 
На рис. $1 б$ (цифра 18) также показана позиция раннекаменноугольных габброгранитных интрузий Магнитогорской группы, с которыми в ММ3 связано крупное скарново-магнетитовое и титаномагнетитовое оруденение. Эти интрузии образуют цепь субмеридионально вытянутых массивов, расположение которых контролируется рифтогенными разломами Магнитогорско-Богдановского грабена.

Малые интрузии субщелочного балбукского сиенит-диорит-гранит-порфирового комплекса (на рис. 16 - 3) широко распространены вдоль западной и северной периферии ММЗ. Они связаны с разнообразными сдвиго-раздвиговыми структурами коллизионного типа [Серавкин и др., 2001; Знаменский, 2009]. С дайками балбукского комплекса ассоциировано золото-сульфидное, золото-сульфидно-кварцевое и золото-кварцевое оруденение. Особенности состава и структурная позиция этого комплекса не позволяют включать его в состав Ахуново-Петропавловского гранитоидного ареала.

Петропавловский габбро-диорит-граносиенит-гранитный массив в плане (рис. 1б) образует крупное, слабо удлиненное в субмеридиональном направлении тело. Он находится в центральной части данного ареала, где прорывает образования девона, а также отложения шумилинской свиты позднефранско-раннекаменноугольного возраста. В составе Петропавловского массива выделяются два комплекса: более ранний собственно петропавловский и более поздний - мосовский [Жданов и др., 2003].

Ранний петропавловский габбро-диорит-гранодиоритовый комплекс подразделен на две фазы. Первая представлена нормальными мезократовыми и меланократовыми габброидами, габброноритами и лейкогаббро. Встречаются клинопироксениты, горнблендиты и оливиновые меланогаббро. Для некоторых габброидов характерны элементы ритмичного строения, с появлением в ритмах тонких прослоев анортозитов, чередующихся с мелано- и лейкогаббро. К первой фазе относятся также габбродиориты и диориты, образующие самостоятельные интрузивные тела или имеющие фациальные переходы с лейко- и мезократовым габбро. Жильная фация здесь представлена дайками габбро-порфиритов. Вторая фаза сложена кварцевыми диоритами, гранодиоритами, порфировидными гранитами, дайками гранодиорит-порфиров. Гранодиориты этой фазы

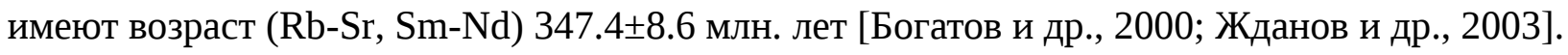
C метасоматитами и гидротермалитами II фазы связана золоторудная кварцево-жильная (шеелитсодержащая), золото-полисульфидно-кварцевая и медно-порфировая минерализация.

В контурах Петропавловского массива присутствуют умереннощелочные породы, ранее выделяемые как мосовский комплекс [ Жданов и др., 2003]- порфировидные монцодиориты, кварцевые сиениты, монцониты, граносиениты и щелочнополевошпатовые граниты. Они секут породы раннего петропавловского комплекса, сопровождаются гумбеитами, кварц-серицитовыми и карбонат-кварцевыми метасоматитами.С ними связано оруденение золото-полисульфидно-кварцевой формации.

В южной части Петропавловский массив рассекается дайками высокотитанистых габбродолеритов. Эти породы по составу близки к позднепалеозойской (330-310 млн. лет) габбро-лампрофировой ассоциации, завершающей рифтогенный магматизм в Магнитогорско-Богдановском грабене [Салихов и др., 2019].

Ахуновский и Карагайский гранитные массивы приурочены к западной части описываемого ареала: Ахуновский массив - на севере, а Карагайский массив - на юге. В плане они образуют (рис. 1) слегка вытянутые в субмеридиональном направлении тела. Массивы объединены в ахуново-карагайский комплекс, который является самой крупной 
группой интрузий Ахуново-Петропавловского ареала. С-3 контакт Ахуновского массива имеет тектоническую природу; это надвиг с восточным падением сместителя, осложненный крутопадающими разломами [Жданов и др., 2003]. В их эндо- и экзоконтактах породы катаклазированы и милонитизированы; участками проявлены ореолы ороговикования. На востоке гранитоиды ахуново-карагайского комплекса прорывают породы Петропавловского массива.

Ахуново-карагайский комплекс представлен двумя фазами [Жданов и др., 2003], первая из которых развита в Ахуновском массиве, вторая - в Карагайском. I фаза включает в себя гранодиориты, адамеллиты, биотит-амфиболовые граниты, в подчиненных количествах — плагиограниты, а также дайки плагиогранит - и гранитпорфиров. Эти дайки наблюдаются как среди пород комплекса, так и среди гранитов Петропавловского массива и во вмещающих отложениях девона. Ко II фазе относятся биотитовые и амфибол-биотитовые граниты, участками мусковитизированные. Дайковый комплекс представлен гранит- и лейкогранит-порфирами, аплитами и пегматитами. С гранитоидами Ахуново-карагайского комплекса ассоциируют оксеталиты и кварцевые жилы, несущие золотое оруденение. Гранитоиды данного комплекса датированы разными методами [Богатов, Костицин, 1999; Богатов и др., 2000; Шатагин и др., 2000; Жданов и др., 2003; Ферштатер, 2013]. Гранодиориты и биотит-амфиболовые граниты Ахуновского массива имеют U-Pb (по циркону) возраст $310 \pm 2$ и 308 \pm 4.4 млн. лет, Rb-Sr и Sm-Nd методами получены близкие цифры - 306.8 \pm 1.8 млн. лет. Биотитовые граниты

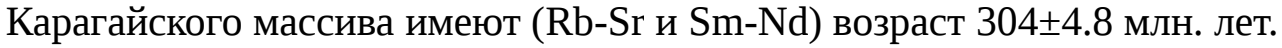

Уйскоборский граносиенит-гранитный массив расположен в восточной части Ахуново-Петропавловского ареала. Ранее он включался в состав ахуново-карагайского комплекса [Жданов и др., 2003]. Ю-В граница Уйскоборского массива представляет собой листрический разлом, вблизи которого гранитоиды катаклазированы и милонитизированы. Массив сложен среднезернистыми массивными порфировидными граносиенитами, адамеллитами и гранитами. Жильные образования представлены дайками гранитпорфиров и аплитов. Sm-Nd и Rb-Sr датировки гранитоидов составляют $304 \pm 4.8$ млн. лет [Богатов, Костицин, 1999; Богатов и др., 2000].

Ранее авторами [Холоднов и др.,2017] были проведены детальные микрозондовые исследования состава породообразующих и ряда (апатита и др.) акцессорных минералов гранитоидных интрузий Ахуново-Петропавловского ареала. Было установлено, что составы породообразующих минералов характеризуют различные физико-химические условия формирования интрузий этого ареала. По данным геотермобарометров [Otten, 1984; Hammarstrom, Zen, 1986; Schmidt, 1991; Henry et al., 2005], наблюдается последовательное изменение Р-Т параметров и глубины становления интрузий: от более глубинного Петропавловского (4-5 кбар) - к менее глубинным Ахуновскому и Карагайскому (2.5-1.5 кбар) массивам и далее - к наиболее молодому гипабиссальному Уйскоборскому (1.0-0.5 кбар) массиву. Состав биотитов отражает нарастание железистости, щелочности и активности калия $\left(\mu \mathrm{K}_{2} \mathrm{O}\right)$ от раннего Петропавловского массива к позднему Уйскоборскому. Состав апатита свидетельствует о формировании ранних габброидов Петропавловского массива в условиях высокой активности хлора [Холоднов и др., 2013, 2017]. Для апатита ахуново-карагайского комплекса хлор не характерен, в его составе появляется $\mathrm{SO}_{3}$. В Уйскоборском массиве, несмотря на то, что его породы обогащены калием, содержание фтора в апатитах остается невысоким, несколько увеличивается содержание $\mathrm{Cl}$ и присутствует $\mathrm{SO}_{3}$. 


\section{ПЕТРОГЕОХИМИЧЕСКАЯ ХАРАКТЕРИСТИКА ГРАНИТОИДОВ АХУНОВО-ПЕТРОПАВЛОВСКОГО АРЕАЛА}

\section{Петрогенные элементы в породах ареала}

По химическому составу гранитоиды Ахуново-Петропавловского ареала относятся преимущественно (рис. 2) к породам с нормальной (петропавловский комплекс, Ахуновский массив) или умеренно-повышенной щелочностью (сиениты и граносиениты в составе Петропавловского массива, Уйскоборский массив, часть поздних даек Карагайского массива). В целом породы Петропавловского массива приближаются к типичным известково-щелочным калий-натриевым сериям. По соотношению алюминия, кальция и щелочей они тяготеют к полю метаглиноземистых разностей (рис. 2б). Ахуновский и Карагайский массивы - перглиноземистые, а Уйскоборский массив выделяется самыми низкими значениями $\mathrm{Al} /(\mathrm{Na}+\mathrm{K})$. Химический состав пород приведен в табл. 1-3, особенности наглядно иллюстрирует рис. 3. .

В породах Ахуновского и Карагайского массивов натрий существенно преобладает над калием: $\mathrm{K}_{2} \mathrm{O}$ не превышает 2-3 мас.\%, $\mathrm{Na}_{2} \mathrm{O}-4-6$ мас.\%. Ранее эти массивы были выделены в малокалиевую группу [Холоднов и др., 2009]. На рис.За породы Ахуновского и Карагайского массивов образуют свой тренд составов - с ростом содержаний $\mathrm{SiO}_{2}$ и $\mathrm{K}_{2} \mathrm{O}$ от Ахуновского массива к Карагайскому.

Породы Петропавловского массива имеют повышенное содержание калия, с ростом содержаний кремнезема и калия от габброидов к гранитам. Для габбро и диоритов этого массива характерен также разброс содержаний $\mathrm{MgO}$ (10.5 - 12.5 мас.\%) и $\mathrm{Al}_{2} \mathrm{O}_{3}$ (8-12 мас.\%), при $\mathrm{CaO}$ - 10-12 мас.\%. Максимальные содержания $\mathrm{Al}_{2} \mathrm{O}_{3}$ (до 21 мас.\%) и $\mathrm{Na}_{2} \mathrm{O}$ (56 мас.\%) наблюдаются в монцодиоритах. Содержания $\mathrm{TiO}_{2}$ в породах Петропавловского массива не превышают 0.90 мас.\%.

Для Уйскоборского массива характерны высокие содержания $\mathrm{K}_{2} \mathrm{O}$ (3.5-5.0 мас.\%), близкие - $\mathrm{Na}_{2} \mathrm{O}$ (4-5 мас.\%) (рис. 3), пониженные количества $\mathrm{MgO}$ и $\mathrm{CaO}$ на фоне повышенных содержаний $\mathrm{FeO}, \mathrm{TiO}_{2}$ и $\mathrm{P}_{2} \mathrm{O}_{5}$ (табл. 3).

Гранит-порфиры поздней дайковой серии. Ранее эти образования были выделены в ахуново-петропавловский дайковый комплекс [Салихов, Бердников, 1985]. Дайки гранит-порфиров секут породы Ахуновского и Карагайского массивов.

На диаграммах (рис. 3, 4) их точки занимают особую позицию, выделяются высокими содержаниями $\mathrm{K}_{2} \mathrm{O}$ (4-5 мас.\%) при низких - $\mathrm{CaO}$, MgO, FeO и $\mathrm{TiO}_{2}$. Дайки образуют обогащенный глиноземом линейный тренд составов (рис. Зг), параллельный тренду гранитоидов ахуново-карагайского комплекса и Уйскоборского массива. При этом дайки, рассекающие Ахуновский массив, наиболее богаты глиноземом.

\section{Микроэлементы в гранитоидах ареала}

В породах Петропавловского массива фиксируются повышенные содержания крупноионных литофильных (Ba, Rb, Sr, Th) и сидерофильных (Cr, Ni, Co, V, Sc) элементов (табл. 1). В наиболее магнезиальных габброидах содержание Сr составляет 300560 г/т, снижаясь до 100 г/т и менее - в диоритах, граносиенитах и гранитах. Максимальные содержания Sr (600-800 г/т) наблюдаются в диоритах и монцодиоритах. Количество $\mathrm{Ba}$ и $\mathrm{Rb}$ (рис. 4a, б) возрастает пропорционально содержанию $\mathrm{SiO}_{2}$ и $\mathrm{K}_{2} \mathrm{O}$ : от габброидов к граносиенитам и гранитам. Содержания высокозарядных элементов $(\mathrm{Nb}, \mathrm{Zr}$ 
и др.) в породах Петропавловского массива невысоки (рис. 4в, е). Поведение элементовпримесей (рис. 5 в, г) свидетельствует об обогащении пород данного массива Y и ТРЗЭ. Суммарное содержание Р3Э, доля ЛР3Э, La/Yb-отношение (от 10 до 16) возрастают от габброидов и диоритов к гранодиоритам и граносиенитам, а в гранитах заметно снижаются (табл. 3). Породы массива имеют слабую положительную (до 1.2) или нулевую аномалию $\mathrm{Eu}$. Для пород характерны также повышенные содержания $\mathrm{Cu}, \mathrm{Pb}, \mathrm{Mo}, \mathrm{W}$, что согласуется со специализацией пород на золоторудную кварцево-жильную, золотополисульфидно-кварцевую и медно-порфировую минерализацию.

Для Ахуновского и Карагайского массивов характерны высокие содержания Ва и $\mathrm{Sr}$, с понижением содержаний Ва в ряду пород: в Ахуновском массиве - от 600 г/т в гранодиоритах до 200-400 г/т в гранитах, в Карагайском — от 1000 г/т в адамеллитах до 400-600 г/т в гранитах (табл. 2). Содержание Sr в Ахуновском массиве возрастает от гранодиоритов к адамеллитам (от 500 до 800-900 г/т), в гранитах резко снижается до 40130 г/т. В Карагайском массиве содержания Sr составляют 1500-500 г/т, наиболее высоки они в гранитах. Для пород ахуново-карагайского комплекса характерны повышенные содержания Li и W, низкие - Rb (20-90 г/т), общее обеднение HFSE - Nb, Zr и др. Содержание $\mathrm{Nb}$ устойчиво понижается (от 5-6 г/т до 1-2 г/т) с ростом содержаний кремнезема и от пород Ахуновского массива - к Карагайскому. Содержание Zr в Ахуновском массиве возрастает от 11 г/т в гранодиоритах до 40-80 г/т в гранитах, а затем в более позднем Карагайском массиве падает от 80 г/т до 15-20 г/т. Породы ахуновокарагайского комплекса обеднены Ү и ТРЗЭ (рис. 5).

Степень фракционирования РЗЭ в Ахуновском и Карагайском массивах выше, чем в Петропавловском, с четким преобладанием ЛРЗЭ над ТРЗЭ. В Ахуновском массиве отношение $\mathrm{La} / \mathrm{Yb}$ составляет 25-35, в Карагайском - 20-30. В позднем Карагайском массиве относительно Ахуновского общее количество РЗЭ в породах понижается (табл. 2). В породах Ахуновского массива, обогащенных плагиоклазом, фиксируется позитивная аномалия Eu (до 1.30). В ряде случаев форма тренды распределения РЗЭ в породах ахуново-карагайского комплекса (рис. 5) характеризуются дефицитом промежуточных лантаноидов (от Gd до Tm). Это может свидетельствовать об отсадке роговой обманки в процессе кристаллизации [Интерпретация..., 2001].

Уйскоборский граносиенит-гранитный массив выделяется повышенными содержаниями Nb, Ta, Zr, Hf, Y и TP3Э, а также U, Th, Pb, Rb, Li, W (табл. 3). C ростом $\mathrm{SiO}_{2}$ пород синхронно растут содержания $\mathrm{Rb}$ - до 100-220 г/т, и $\mathrm{Nb}$ - до 10-12 г/т.

Содержания U увеличиваются до 4-5 г/т, Th до 20-27 г/т, при росте Th/U отношения от 3.7 до 5.6. Для других микроэлементов характерны обратные тенденции. Так, количество Zr с ростом $\mathrm{SiO}_{2}$ пород падает от 130 до 50 г/т (рис. 4в), Y- от 14 до 8 г/т, Yb - от 2 до 0.5 г/т (табл. 3). Снижение содержаний Y и Yb происходит на фоне снижения суммы Р3Э, при выдержанном соотношении легких и тяжелых лантаноидов. По виду трендов Р3Э (рис. 5) гранитоиды Уйскоборского массива существенно отличаются от Ахуновского и Карагайского массивов. В Уйскоборском массиве наблюдается обогащение пород ТРЗЭ, при слабом преобладании ЛРЗЭ над ТРЗЭ (La/Yb =10.0, против 20-35 в ахуновокарагайском комплексе). Кроме того, только здесь появляется резкая негативная аномалия $\mathrm{Eu} \mathrm{(0.30-0.80).} \mathrm{Геохимической} \mathrm{особенностью} \mathrm{пород} \mathrm{Уйскоборского} \mathrm{массива} \mathrm{являются}$ также низкие содержания $\mathrm{Sr}(<400$ г/т) и Ва $(<500$ г/т).

Гранит-порфиры поздней дайковой серии. Эта серия характеризуется самыми низкими в ареале содержаниями $\mathrm{Ba}, \mathrm{Sr}$ и $\mathrm{Nb}$, малым количеством $\mathrm{Zr}$ и слабо повышенным 
- $\mathrm{Rb}$ (рис. 4). Отметим, что отдельные разновидности даек имеют повышенные содержания $\mathrm{Nb}$ и $\mathrm{Zr}$, что сближает их с породами Уйскоборского массива. Возможно, их генерация связана с общим источником.

Все интрузивные комплексы данного ареала, независимо от времени их образования и состава, на спайдеграммах имеют чёткий минимум Nb (рис. 5). При этом Петропавловский, Ахуновский и Карагайский массивы характеризуются четкими положительными аномалиями $\mathrm{Cs}, \mathrm{Rb}, \mathrm{Ba}, \mathrm{Sr}, \mathrm{Th}$ и U, что типично для надсубдукционных образований. Для Уйскоборского массива, обогащенного $\mathrm{Nb}$, характерны резкие минимумы для Ba и Sr, при нарастании амплитуды положительных аномалий $\mathrm{K}, \mathrm{Rb}, \mathrm{Th}, \mathrm{U}$, $\mathrm{Pb}, \mathrm{Zr}$, ТРЗЭ и $\mathrm{Y}$.

На диаграммах Дж. Пирса (рис. 6) точки составов пород Петропавловского, Ахуновского и Карагайского массивов попадают в поле надсубдукционных образований. Они образуют две группы: первую составляют породы Ахуновского и Карагайского массивов (с низкими содержаниями Y и Yb), вторую - породы Петропавловского массива (обогащенные ими). Кроме того, на диаграмме Та-Yb интрузивные породы Ахуновского и Карагайского массивов образуют линейный тренд, где содержания этих элементов пропорционально снижаются, при сохранении отношений $\mathrm{Ta} / \mathrm{Yb}=2(\mathrm{Nb} / \mathrm{Y}=1)$ в диапазоне содержаний $\mathrm{SiO}_{2}$ 65-75 мас.\% . Особое поле образует Уйскоборский массив, характеризующийся высокими содержаниями Та и $\mathrm{Rb}$, и повышенными $-\mathrm{Y}$ и $\mathrm{Yb}$. Точки состава пород этого массива тяготеют к границе с полем синколлизионных гранитов.

\section{О составе источника}

Вклад в магмогенерацию различных источников вещества (обогащенной мантии, субдукционного и осадочного компонентов, флюидного обогащения и др.) - по [Рearce, 1983; Kepezhinskas et al., 1997; Abratis, 1998; Woodhead et al., 2001; Мартынов, 2010; Волынец и др., 2018 и др.] можно оценить по позиции точек пород на рис. 8.

Гранитоиды Уйскоборского массива ближе всего отвечают обогащенному мантийному источнику, с влиянием на его состав процессов кристаллизационной дифференциации и коровой ассимиляции.

Петропавловский массив выделяется значительным вкладом субдукционного компонента и важной ролью процессов флюидно-магматического взаимодействия. Роль мантийного обогащения здесь менее значительна (Тa/Yb $<0.5$, а $\mathrm{Nb} / \mathrm{Y}<1)$.

Ахуново-карагайский комплекс характеризуется существенным вкладом субдукционного флюида, с нарастанием флюидного обогащения от более раннего Ахуновского массива - к Карагайскому. В гранитоидах Ахуновского массива относительно Карагайского более заметна роль и мантийно-плюмового обогащения. Это выражается в более высоких содержаниях $\mathrm{Nb}$ (до 6 г/т) и отношений $\mathrm{Ta} / \mathrm{Yb}$ (до 1) и $\mathrm{Nb} / \mathrm{Y}$ (до 1-2 и более). Значительное число поздних даек в Ахуново-Петропавловском ареале формируется уже при более высокой роли коровой контаминации, о чем свидетельствует рост в них $\mathrm{Th} / \mathrm{Yb}-о$ оношения.

\section{ОБСУЖДЕНИЕ РЕЗУЛЬТАТОВ}

Постостроводужные аккреционно-коллизионные процессы (поздний девон-карбон), сформировавшие активную континентальную окраину на Южном Урале, характеризовались субсинхронным проявлением разнонаправленных тектонических движений и магматических проявлений. Эта особенность отражена в различных типах 
серий, присутствующих в трех основных структурно-формационных зонах (рис. 1) ММ3, причлененной в позднем девоне к окраине ВЕК.

В Центрально-Магнитогорской подзоне (ЦМП) в раннем-среднем карбоне процессы коллизионных сдвиго-раздвиговых деформаций, рифтогенного растяжения и грабенообразования проявлялись наиболее интенсивно. В раннем карбоне начал формироваться Магнитогорско-Богдановский грабен, локальные раздвиги в котором контролировали начальные трещинные излияния высокотитанистых (до $3.0 \% \mathrm{TiO}_{2}$ ) субщелочных калий-натровых базальтов (греховский комплекс) и эффузивов, связанных с вулканами центрального типа (березовский комплекс) - [Салихов и др., 2014, 2016, 2019]. Базитовый магматизм сопровождался значительными по масштабам проявлениями субщелочных пород трахидацит-риолитовой ассоциации. По соотношению микроэлементов базальты Магнитогорско-Богдановского грабена соответствуют внутриплитным образованиям. Вместе с тем, на их состав заметное влияние оказывает и общая надсубдукционная обстановка АКО, островодужный субстрат вмещающих вулканогенных толщ, а также наличие блоков океанической коры в фундаменте Магнитогорской энсиматической островной дуги [Серавкин и др., 2001]. Поэтому базальты грабена выделяются заметной долей неплюмового субдукционного вещества (рис. 8). Распределение микроэлементов в кислых вулканитах близко к их спектру в базальтах, с ростом соотношений $\mathrm{Nb} / \mathrm{Yb}, \mathrm{Nb} / \mathrm{Y}$, Th/Yb и $\mathrm{Zr} / \mathrm{Y}$ в сторону более дифференцированных и контаминированных пород [Салихов и др., 2019].

Интрузивные образования Магнитогорско-Богдановского грабена выделены в Магнитогорскую габбро-гранитную серию, которая характеризует процесс новой среднекаменноугольной (визе) рифтогенной активизации ЦМП [Салихов и др., 2014, 2016]. Габброиды этой ассоциации представлены куйбасовским и богдановским комплексами. По составу они, даже в большей степени, чем базальты, отвечают базитам внутриплитного типа: на рис. 8 их точки близки к линии мантийной последовательности, отвечая E-MORB. В габброидах куйбасовского комплекса присутствуют тела сплошных титаномагнетитовых руд (месторождение Малый Куйбас).

Особенностью интрузивных пород Магнитогорской рифтогенной вулканоинтрузивной ассоциации являются высокие концентрации хлора в расплавах и флюидах [Холоднов, Бушляков, 2002]. Это в условиях окислительного режима магнетитовой феррофации [Ферштатер, 1987] повлияло на массовую экстракцию Fe хлороносным флюидом, с формированием ряда крупных скарново-магнетитовых месторождений (Магнитогорское, Малый Куйбас).

По времени (ранний карбон), магматическим и флюидным источникам внутриплитный магматизм ЦМП и ассоциированное с ним оруденение были, повидимому, наиболее тесно связаны с внедрением в новообразованную окраинноконтинентальную литосферу ММЗ горячего астеносферного диапира (плюма) и его взимодействием с ее островодужным и океаническим субстратом. На этом возрастном рубеже субдукция, из-за активных конвергентных движений, затормозилась, зона субдукции заклинилась, произошел разрыв слэба, что способствовало подъему астеносферного диапира-плюма в область мантийного клина и нижней коры [Салихов, Митрофанов,1994; Язева, Бочкарев, 1998; Пучков, 2010; Салихов и др., 2014]. Интенсивность взаимодействия плюмового вещества с деплетированным океаническим субстратом в фундаменте ММЗ определяет, по-видимому, геохимические и изотопные характеристики пород Магнитогорско-Богдановского грабена. Геохимические особенности 
вулканогенных и интрузивных пород грабена отражены на рис. 8, более детально они описаны в работах [Салихов и др., 2014,2016, 2019].

Изотопно-геохимические и геохронологические данные также характеризуют интенсивность плюм-литосферного взаимодействия. Магнитогорская габбро-гранитная серия сформировалась в диапазоне 340-330 млн лет, ее изотопно-геохимические параметры: ${ }^{87} \mathrm{Sr}^{86} \mathrm{Sr}_{0}=0.70313, \varepsilon \mathrm{Sr}_{\mathrm{T}}-26.57 \ldots$-26.64., $\varepsilon \mathrm{Nd}_{\mathrm{T}}+5.90 \ldots+5.80$ [Ронкин, 1989; Ронкин и др., 2006]. Эти значения существенно отличаются от величин, характеризующих завершающий этап островодужного магматизма ММЗ. Так, позднеостроводужый Верхнеуральский монцодиорит-граносиенитовый массив имеет возрастом $362 \pm 9$ млн. лет [Салихов, Митрофанов, 1994] и ${ }^{87} \mathrm{Sr}^{86} \mathrm{Sr}_{0}=0.70449, \varepsilon \mathrm{Sr}_{\mathrm{T}}-6.86, \varepsilon \mathrm{Nd}_{\mathrm{T}}+1.50$. Кора островодужного типа в ММЗ на этом этапе достигла уже значительной степени зрелости. Процессы рифтогенеза и грабенообразования в раннем карбоне вызвали ее существенную деструкцию, с насыщением новым, более деплетированным мантийным материалом.

Завершают интрузивный магматизм этого грабена и ЦМП в целом многочисленные малые интрузии долеритов, диорит-порфиритов, сиенит- и гранит-порфиров с возрастом 330-310 млн. лет [Салихов и др., 2014; 2019]. Все они обладают чертами как надсубдукционных, так и внутриплитных образований. Некоторые из них (балбукский комплекс) сопровождаются золоторудной минерализацией.

В Западно-Магнитогорской подзоне (ЗМП) ММЗ в структурах, частично надвинутых на краевую часть ВЕК, рифтогенные процессы в карбоне имели менее развитый характер. Здесь формировались узкощелевые сдвиго-раздвиговые структуры (мульды) трансформного типа, где внедрялись конформные вмещающим толщам интрузии габбродолеритов и габбродиоритов, имеющие «пестрый» состав. Одни из них имеют внутриплитные геохимические характеристики, а другие - надсубдукционные. Первый тип (утлыкташский комплекс) характеризуется более высоким содержанием титана $\left(\mathrm{TiO}_{2}\right.$ до $\left.3.0 \%\right)$ и фосфора $\left(\mathrm{P}_{2} \mathrm{O}_{5}\right.$ до $\left.0.54 \%\right)$, ближе соответствуя толеитовым сериям. С этим типом интрузий связано формирование скарново-магнетитовых руд небольшого Канакайского месторождения. Другие, такие как файзуллинский комплекс, выделяются высокой магнезиальностью пород (MgO до 14 мас.\%), они более обогащены LILE. Третий тип, особенно интрузии в структуре Худолазовской мульды (басаевский комплекс), выделяются не только повышенной магнезиальностью пород, но и значительно более высокими содержаниями $\mathrm{Ni}$ и $\mathrm{Cr}$.

Более молодой этапом магматизма в ЗМП представлен базит-ультрабазитовыми интрузиями худолазовского комплекса, специализированными на сульфидное $\mathrm{Cu}-\mathrm{Ni}$ оруденение. По составу они также отвечают высокомагнезиальным разностям и варьируют от роговообманковых перидотитов (шрисгеймитов) и оливиновых габбродолеритов до габбродиоритов. Их внедрение контролируется многочисленными разрывными нарушениями, что свидетельствует о синтектонической природе. Время формирования худолазовского комплекса - 324-328 млн. лет [Салихов и др., 2012]. Для пород данного комплекса, содержащего $\mathrm{Cu}-\mathrm{Ni}$ оруденение, характерны акцессорные апатиты [Холоднов и др., 2015] с наиболее высокими в ЗМП содержаниями сульфатной серы (до 0.65 мас.\%) и хлора (до 1.50 мас.\%).

Магматизм в ЗМП завершается формированием дайковой серии улугуртауского лампрофир-долеритового комплекса. Его изохронный Sm-Nd возраст - 321 млн. лет. С этим комплексом ассоциированы рудопроявления золота. 
В Восточно-Магнитогорской подзоне (ВМП), в ее северной части, наиболее сильно сжатой позднепалеозойскими коллизионными процессами, интрузивный магматизм в карбоне заметно отличается по составу, генезису и геодинамической обстановке от магматизма ЦМП и ЗМП. Здесь присутствуют крупные мантийно-коровые анатектические батолиты (Сыростанский, Заматохинский, Ахуновский и Карагайский), не известные в других структурно-формационных зонах ММЗ. Их внедрение было связано с усилением процессов субширотного сжатия, которые во времени чередовались с этапами коллизионных сдвиго-раздвиговых деформаций и рифтогенного растяжения.

В Ахуново-Петропавловском ареале, на раннем этапе растяжения, сформировался многофазный Петропавловский массив, датированный возрастом $347 \pm 8.6$ млн лет.

Как было показано выше, его породы характеризуются самой высокой в ареале магнезиальностью. По составу ранних фаз и их хлороносности он близок к файзуллинскому габбродолеритовому комплексу в ЗМП. От последнего Петропавловский массива отличается более высокой степенью магматической дифференциации, с образованием поздних фаз монцодиорит-граносиенит-гранитного состава. Это, по-

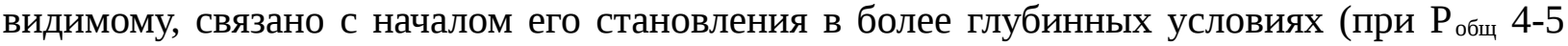
кбар). Повышенная хлороносность габброидов Петропавловского массива указывает на связь с одним из ранних этапов растяжения, так как высокие содержания $\mathrm{Cl}$ в апатитах обычно характерны для габбро-гранитных серий, связанных с рифтогенезом [Холоднов, Бушляков, 2002].

По составу породы Петропавловского массива близки к надсубдукционным образованиям, отличаясь от других интрузий Ахуново-Петропавловского ареала высокими содержаниями $\mathrm{Y}$ и $\mathrm{Yb}$. По этому признаку данный массив близок к позднеостроводужным гранитоидам Магнитогорской палеодуги (Краснинский габбродиорит-гранодиоритовый и Верхнеуральский монцодиорит-граносиенитовый массивы), предшествующим ему по времени [Ферштатер, 2013]. Это сходство подтверждается и близостью изотопно-геохимических данных [Богатов, Костицын, 1999; Шатагин и др., 2000; Попов и др., 2002; Жданов и др., 2003 и др.], с небольшим сдвигом изотопных параметров Петропавловского массива в сторону более деплетированного источника. Верхнеуральский массив имеет ${ }^{87} \mathrm{Sr}^{86} \mathrm{Sr}_{0}=0.70449-0.70465, \quad \varepsilon \mathrm{Nd}(\mathrm{T})+1.50$, а Петропавловский массив $-{ }^{87} \mathrm{Sr} /{ }^{86} \mathrm{Sr}_{o}=0.70451,{ }^{143} \mathrm{Nd} /{ }^{144} \mathrm{Nd}=0.512344, \varepsilon \mathrm{Nd}(\mathrm{T})+2.97$. Связь с зоной субдукции подтверждаются также низкими содержаниями Тi, высокими - Sr, Ba и других крупноионных литофильных элементов. От габброидов Магнитогорского грабена базиты Петропавловского массива отличаются более высокими Th/Yb-отношениями (рис. 8). Несмотря на пониженные количества в породах этого массива высокозарядных элементов, по их соотношениям ( $\mathrm{Nb} / \mathrm{Y}$ и $\mathrm{Zr} / \mathrm{Y})$ они близки рифтогенным образованиям Магнитогорско-Богдановского грабена.

Ахуново-карагайский комплекс формируется позднее Петропавловского массива, в обстановке следующих этапов субширотного сжатия (стресса) и тектонического скучивания, когда движение внутриплитных мантийных магм в коре было затруднено. Это способствовало росту интенсивности анатектического плавления в низах коры и в подстилающей зоне андерплейтинга [ Ферштатер,2013], усилению мантийно-корового и флюидно-магматического взаимодействий. Возрастной перерыв между образованием Петропавловского массива и ахуново-карагайского комплекса в едином ареале - около 40 млн. лет (347 и 310-306 млн. лет). 
По составу и условиям формирования гранитоиды Ахуновского и Карагайского массивов близки к окраинно-континентальным полихронным батолитам и комплексам габбро-тоналит-гранодиорит-гранитного (ГТГГ) состава. Эти батолиты (Верхисетский, Челябинский и др.) и ГТГГ-серии образуют на Урале две основные возрастные группы: 365-355 млн. лет и 320-290 млн. лет [Ферштатер, 2013; Ферштатер и др., 2018]. Породы ахуново-карагайского комплекса по возрасту соответствуют массивам второй возрастной группы. В эту группу входят и пространственно обособленные от батолитов самостоятельные гранитные интрузии, такие как Шарташский и Каменский гранитные массивы на Среднем Урале или Пластовский, Чернореченский и другие на - Южном. Соответствие массивам второй возрастной группы имеет важное прогнознометаллогеническое значение, поскольку с такими объектами на Среднем и Южном Урале связаны многочисленные золоторудные месторождения, в частности, такие крупные как Березовское и Кочкарское.

Массивы второй группы (поздний карбон) близки друг к другу и по геохимическим признакам. Все они характеризуются низкими концентрациями высокозарядных элементов: Nb, Ta, Y, Yb, Zr и др. В нашем случае от пород более раннего Ахуновского массива к Карагайскому происходит дальнейшее устойчивое снижение содержаний этих элементов. Содержание $\mathrm{Nb}$ с ростом $\mathrm{SiO}_{2}$ в породах этих массивов уменьшается от 5-6 г/т до 1-2 г/т.

В то же время, габбро, диориты, тоналиты, гранодиориты более ранней (365-355 млн. лет) возрастной группы (Верхисетский, Челябинский батолиты), включая в этот набор и близкие по составу породы в Сыростанском батолите (север ММ3), характеризуются существенно более высокими начальными содержаниями $\mathrm{Nb}$ (до 30-40 г/т), Та (до 3-4 г/т), Y (до 30-40 г/т), Yb (до 2-3 г/т) [Ферштатер, 2013; Ферштатер и др., 2018]. Такой уровень концентраций приближает их к геохимическим параметрам внутриплитных плюм-зависимых образований [Холоднов и др., 2017б].

Отметим, что начальные члены серий ранней возрастной группы в ГТГГкомплексах по концентрациям HFSE образуют с гранитами второй группы последовательный ряд составов. К гранитам существенно снижаются содержания $\mathrm{Nb}$, Ta, $\mathrm{Zr}$ и др. HFSE, отражая последовательность анатектических выплавок во времени: от более высокотемпературных (габбродиориты) к низкотемпературным (граниты). По данным [Воронцов и др., 2015, 2018], снижение концентраций Zr на фоне роста содержаний $\mathrm{SiO}_{2}$ в одновозрастных породах - это доказательство участия в магмообразовании анатектических коровых выплавок. Этапы анатектического гранитообразования на Урале в ГТГГ-сериях сопровождались внедрением синплутонических даек габброидов и гранитоидов повышенной основности, также обогащенных $\mathrm{Nb}$ (до 20 г/т) и Y (до 30 г/т). Такие дайки известны в Сыростанском, Челябинском и Верхисетском батолитах [Зинькова, Ферштатер, 2007; Каллистов, Осипова, 2017].

Батолитообразование, синхронное с рифтогенно-плюмовым магматизмом, имеет место на конвергентных границах, формирующихся над мантийными плюмами на краю континентов [Ярмолюк, Кузьмин и др., 2013]. Такой тип конвергентных границ выделяется как западно-тихоокеанский. Предполагается, что такие границы имели место при формировании Центрально-Азиатского складчатого пояса. На участках континентальных окраин Сибирского континента одновременно с рифтогенным внутриплитным плюмзависимым магматизмом формируются крупные (Ангаро-Витимский, Хангайский и др.) 
гранитные батолиты [Владимиров и др., 1999; Крук, 2015; Цыганков и др., 2016]. На участках, подвергшихся наиболее сильным стрессовым воздействиям, которые типичны для АКО [Ярмолюк и др., 2018], мантийные плюмовые расплавы не поднимались выше низов коры. Их тепловое и флюидное воздействие вызывало анатексис в низах коры и подстилающей зоне нижнекорового магматического андерплейтинга, и определяло образование крупных мантийно-коровых гранитоидных батолитов. Формирование в позднем палеозое конвергентной границы западно-тихоокеанского типа могло быть характерно и для Уральского подвижного пояса.

Синхронность корового батолитообразования с рифтогенным плюм-зависимым мантийным магматизмом на Урале проявляется по-разному. Крайне редко действительно наблюдается одновременное проявление рифтогенного мантийного и надсубдукционного корово-анатектического магматизма. Происходит это в случае значительного удаления зон магмообразования друг от друга. В частности, таким примером является синхронное формирование Магнитогорской рифтогенной габбро-гранитной серии (340-330 млн. лет) и Сыростанского батолита (335-325 млн лет). Последний приурочен к месту сочленения Магнитогорской палеодуги (на ее крайнем северо-западе) с краем BEK, то есть западному краю ГУР - зоне с наиболее интенсивными аккреционно-коллизионными процессами. В большинстве других случаев процессы надсубдукционного (аккреционно-коллизионного) анатектического гранитоидного магматизма, ведущего к образования батолитов, отделены по времени от рифтогенного магмообразования. Как было показано выше, при формировании батолитов ГТГГ-типа выделяются две возрастные группы (365-355 и 320290 млн. лет): первая предшествует главному этапу рифтогенеза в ММ3, а вторая проявляется после него. В ММЗ второму этапу отвечает формирование ахуновокарагайского гранитоидного комплекса (310-306 млн. лет). В этом случае зоны мантийного рифтогенеза и корового магматизма также разделены в пространстве, но временной промежуток между ними гораздо короче.

Уйскоборский граносиенит-гранитный массив (304 \pm 4.8 млн лет) завершает гранитоидный магматизм в Ахуново-Петропавловском ареале. По составу и РТ-условиям формирования он является весьма специфическим образованием, не известным ранее на восточном склоне Ю. Урала и впервые выделенным в ММЗ. Выяснилось, что Уйскоборский массив генетически не связан с предшествующими ему во времени гранитоидами ахуново-карагайского комплекса. Этот массив представляет собой гипабиссальную, бедную водой и другими летучими, относительно высокотемпературную и дифференцированную интрузию. Вероятнее всего, она по источнику представляет собой продукт эволюции обогащенного высокозарядными элементами, субщелочного исходного расплава, значительно дифференцированного в глубинной промежуточной магматической камере. Специфика состава пород этого массива также связана с формированием его в эпоху (конец карбона-ранняя пермь) перехода от окраинно-континентальной обстановки к жесткой коллизии между ВЕК и Казахстанским палеоконтинентом. По этой причине, с одной стороны, в составе пород этого массива сохраняются некоторые геохимические признаки надсубдукционных образований, а с другой - появляются черты, характерные для синколлизионных серий.

Сочетание ряда структурных, минералогических и геохимических признаков указывает на близость пород Уйскоборского массива к гранитоидам А-типа [Гребенников, 2014 и др.]. А-граниты часто генерируются при режимах локального рифтогенного растяжения, проявляющихся внутри или на окраинах континентов вследствие 
постсубдукционных и постколлизионных процессов. Они также формируются в зонах с переменчивой геодинамической обстановкой, когда встречное движение плит у конвергентной границы может сменяться на их сдвиговое перемещение относительно друг друга, что соответствует понятию «трансформная континентальная окраина» [Ханчук и др., 1997]. Подобная геодинамическая ситуация, на фоне смены субдукционного режима на коллизионный, характерна, например, для гранитоидов Наушкинского массива в Западном Забайкалье [Донская, Мазукабзов, 2014].

Появление гранитоидов А-типа маркирует воздействие на литосферу и аномальных мантийных источников [Крук, 2015]. Яркий пример - внутриплитый гранитоидный магматизм А-типа в Горном Алтае, проявленный во франское время. Он сопровождается щелочными бимодальными вулканическими сериями, начинающимися с базальтов типа OIB (с $\left.\varepsilon \mathrm{Nd}_{\mathrm{T}} \geq+8\right)$, а кислые разности обогащены HFSE и РЗЭ и имеют $\varepsilon \mathrm{Nd}_{\mathrm{T}}+6.5$. Их формирование рассматривается как результат взаимодействия щелочно-риолитовых магм (дифференциатов обогащенных мантийных расплавов) с коровыми выплавками.

На рис. 9 на фоне общей схемы изотопно-геохимической эволюции палеозойского магматизма Урала в возрастном диапазоне 420-250 млн лет (большое поле, со стрелкой, направленной вниз) приведены данные для пород Ахуново-Петропавловского ареала. В отличие от магматитов Уральского орогена, направление эволюции изотопногеохимических параметров при гранитообразовании в данном ареале прямо противоположно: от Петропавловского и Верхнеуральского массивов - к интрузиям ахуново-карагайского комплекса и далее к Уйскоборскому массиву (на рис. 9, стрелка, направленная вверх для $\varepsilon N d$ - возраст (а) и $\varepsilon N d ~-{ }^{87} \mathrm{Sr}^{86} \mathrm{Sr}_{0}$ (б)). Поля отдельных гранитоидных батолитов Урала выделены по данным [Богатов и др., 2000; Ронкин, 1989; Шатагин и др., 2000; Попов и др., 2002; Тевелев и др., 2006; Осипова и др., 2009; Ронкин и др., 2006; Смирнов и др., 2016]. Видно, что эти плутоны заметно отличаются друг друг по соотношениям $\varepsilon \mathrm{Nd}-$ возраст и $\varepsilon \mathrm{Nd}-{ }^{87} \mathrm{Sr} /{ }^{86} \mathrm{Sr}_{0}$. Это указывает на их формирование из различного субстрата, а также на разную интенсивность процессов мантийно-корового взаимодействия, наиболее высокую, например, для пород Челябинского (карбон) ГТГГбатолита. Более молодой (пермь) синколлизионный Джабыкский плутон по параметрам уже отвечает [Холоднов и др., 2016] этапу формирования наиболее зрелой континентальной коры Уральского орогена.

Гранитоиды ахуново-карагайского комплекса и Уйскоборского массива наиболее близки по изотопно-геохимическим параметрам к породам Верхисетского ГТГГ батолита, отражая связь с более деплетированным источником. Также по соотношению $\varepsilon \mathrm{Nd}-$ возраст к этому типу близки породы Магнитогорской рифтогенной габбро-гранитной серии, но они имеют более низкое первичное отношение Sr. Можно предположить, что относительно высокая изотопно-геохимическая деплетированность пород Уйскоборского массива и ахуново-карагайского комплекса в позднем карбоне и раннекаменноугольных бимодальных вулканогенных и интрузивных комплексов Магнитогорско-Богдановского грабена была связана с общим для них процессом плюм-литосферного взаимодействия. Мантийный диапир-плюм в условиях активной окраины, имеющей в составе фундамента блоки океанической коры, в зоне “слэб-виндоу” активно с ними взаимодействовал, в результате мантийные и мантийно-коровые (анатектические) обогащались сильно деплетированным веществом. Блок офиолитов, имеющий предположительно раннесилурийский возраст (буйдинский комплекс) и характеризующий состав океанической коры в фундаменте ММЗ, находится вблизи западного контакта Ахуновского 
гранитного массива [Серавкин и др., 2001]. Это означает, что наряду с обогащенным плюмовым веществом, в процессах анатектического плавления могли участвовать также обогащенные водой серпентинизированные породы офиолитовой ассоциации.

\section{ЗАКЛЮЧЕНИЕ}

Ахуново-Петропавловский ареал позднепалеозойского гранитоидного магматизма, расположенный на северо-востоке ММ3, представляет собой ряд последовательных во времени гранитоидных интрузий (Петропавловской, Ахуновской, Карагайской и Уйскоборской), которые связаны с различными магматическими и флюидными источниками (субдукционными и внутриплитными рифтогенно-плюмовыми).

Этот крупный по размерам, но компактный по строению ареал существенно отличается от проявлений интрузивного магматизма и рудогенеза в центральной и западной частях ММЗ. В этих секторах наряду с аккреционно-коллизионными процессами, обусловленными столкновением Магнитогорской палеодуги и ВЕК, проявляется интенсивная рифтогенная деструкция, сопровождаемая в интервале 340330 млн лет внутриплитным плюм-зависимым магматизмом. В результате в центральной части ММЗ сформирована Магнитогорская вулкано-интрузивная серия, широко развитая в Магнитогорско-Богдановском грабене, вытянутом вдоль меридиана более чем на 200 км. Эта серия сложена продуктами базальт-риолитового состава и комагматичными им габбро-гранитными интрузиями и дайками. Гранитоиды этой серии обогащены высокозарядными элементами, имеют специализацию на крупное скарново-магнетитовое оруденение.

В Западно-Магнитогорской подзоне в структурах, частично надвинутых на краевую часть ВEK, рифтогенные процессы в карбоне имели менее развитый характер. Здесь формировались узкощелевые сдвиго-раздвиговые структуры (мульды) трансформного типа, по которым внедрялись трещинные интрузии габбродолеритов и диоритов. В одних из них доминируют внутриплитные геохимические характеристики, а в других - надсубдукционные. Базит-ультрабазиты худолазовского комплекса, имеющие возраст 324-328 млн. лет, специализированы на сульфидное $\mathrm{Cu}-\mathrm{Ni}$ оруденение.

В Восточно-Магнитогорской подзоне, в ее северной части, наиболее сжатой коллизионными процессами, на этапах усиления субширотного стресса, происходило формирование полихронных мантийно-коровых анатектических гранитоидных батолитов, неизвестных в других частях ММЗ. Во времени их формирование чередовалось с этапами коллизионных сдвиго-раздвиговых деформаций и рифтогенного растяжения. В АхуновоПетропавловском ареале наиболее ранним членом ряда является мезоабиссальный

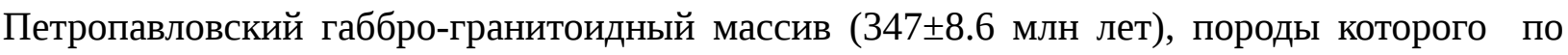
петрогеохимии наиболее близки к надсубдукционным образованиям, представляющим собой продукт плавления надсубдукционного мантийного субстрата, обогащенного не только водным флюидом, но и хлором. Затем в интервале 310-306 млн лет имели место процессы коллизионного сжатия и образование корово-анатектических интрузий ахуновокарагайского гранодиорит-гранитного комплекса, породы которого близки к окраинноконтинентальным ГТГГ батолитам с возрастом 320-290 млн. лет, специализированным (Шарташский, Каменский массивы и т.п.) на крупное золото-сульфидно-кварцевое оруденение (Березовское месторождение и др.).

На завершающем этапе формирования ареала, при усилении сдвиго-раздвиговых деформаций образовался Уйскоборский граносиенит-гранитный массив $(304 \pm 4,8$ млн. лет), богатый калием и высокозарядными элементами. Это была эпоха перехода от 
окраинно-континентального режима к жесткой коллизии между Восточно-Европейским и Казахстанским континентами. Вероятно, поэтому породы Уйскоборского массива сохраняют некоторые геохимические особенности, присущие надсубдукционным сериям, но при этом приобретают признаки синколлизионных и рифтогенно-плюмовых образований. Они также имеют черты сходства с А-гранитами. Такой тип гранитоидных интрузий для ММЗ выделен впервые.

Изменение изотопно-геохимических характеристик для пород АхуновоПетропавловского ареала (и в целом для постостроводужных комплексов ММЗ) указывает на эволюцию состава источников. Предполагается, что рост деплетированности магматических источников в карбоне связан с общим процессом плюм-литосферного взаимодействия. В фундаменте ММЗ присутствуют блоки океанической коры, и мантийный диапир, находящийся под АКО Южного Урала, активно взаимодействовал с ними через “слэб-виндоу”. В результате в раннем карбоне сформировалась вулканоинтрузивная Магнитогорская серия, имеющая признаки как внутриплитных плюмзависимых, так и надсубдукционных образований. Протолит, содержащий обогащенный плюмовый компонент и океанический субстрат в зоне магматического андерплейтинга, мог участвовать также и в анатексисе на нижнекоровом уровне. Поэтому массивы ахуново-карагайского комплекса имеют корово-анатектическую природу. Самый молодой Уйскоборский массив тоже мог быть связан с деплетированным плюм-зависимым магматическим источником.

Данное исследование существенно дополняет представления о разнообразии продуктов плюм-литосферного взаимодействия в ходе различных геодинамических обстановок: в океанических плато, на континентах, в энсиматических и энсиалических островных дугах и в зонах АКО. Синхронность процессов магмообразования, идущих на разных уровнях мантии и коры, может быть связана со сменой движений разной направленности. Во-первых, она может иметь место на границах конвергентного типа, формирующихся при действии мантийных плюмов под краем континентов. Во-вторых, со временем в АКО такого типа усиливаются процессы трансформной (сдвиго-раздвиговой) тектоники и рифтогенеза, обусловленные скольжением литосферных плит.

Возможно, благодаря такой сложной геодинамической обстановке в АхуновоПетропавловском ареале образовались гранитоидные комплексы, имеющие разную глубинность, состав серий, изотопно-геохимические особенности, флюидный режим и металлогеническую специализацию. Это позволяет рассматривать данный ареал как один из типичных окраинно-континентальных центров длительного мантийно-корового взаимодействия, где процессы магмообразования происходят на разных уровнях мантии и коры, с участием как надсубдукционных, так и плюм-зависимых рифтогенных источников.

Работа выполнена в рамках бюджетных исследований ИГГ УрО РАН по теме № 0393-2016-0020, № госрегистрации АААА-A18-118052590029-6 и в рамках Государственного задания ИГ УФИЦ РАН по темам № 0252-2017-0012 и 0246-2019-0080.

\section{ЛИТЕРАТУРА}

Богатов В.И., Костицын Ю.А. Rb-Sr изотопный возраст и геохимия гранитоидов на севере Магнитогорского прогиба, Южный Урал // Известия высших учебных заведений, Геология и разведка, 1999, № 2, с. 34-41. 
Богатов В.И., Шатагин К.Н., Чаплыгина Н.Л. Источники коллизионных гранитоидов северной части Магнитогорского прогиба // Коллизионная стадия развития подвижных поясов. VI Чтения А.Н. Заварицкого. Екатеринбург: УрО РАН, 2000, с. 11-12.

Владимиров А.Г., Гибшер А.С., Изох А.Э., Руднев С.Н. Раннепалеозойские гранитоидные батолиты Центральной Азии: масштабы, источники и геодинамические условия формирования // ДАН, 1999, т. 369 (6), с. 795-798.

Волынец А.О. Певзнер М.М., Толстых М.Л., Бабанский А.Д. Вулканизм южной части Срединного хребта Камчатки в неоген-четвертичное время // Геология и геофизика, 2018, т. 59 (12), с. 1979-1996.

Воронцов А.А., Ярмолюк В.В., Федосеев Г.С., Перфилова О.Ю., Посохов В.Ф., Травин А.В., Газизова Т.Ф. Дифференцированная вулканическая ассоциация Минусинского прогиба: механизмы образования и источники расплавов (на примере Батеневского поднятия) // Петрология, 2015, т. 23 (4). с. 386-409.

Воронцов А.А., Перфилова О.Ю., Крук Н.Н. Геодинамическое положение, строение и состав непрерывных трахибазальт-трахиандезит-риолитовых серий северной части Алтае-Саянской области: роль коровомантийного взаимодействия в континентальном магмообразовании // Геология и геофизика, 2018, т. 59 (12), с. 2055-2078.

Гребенников А.В. Гранитоиды А-типа: проблемы диагностики, формирования и систематики // Геология и геофизика, 2014, т. 55 (9), с. 1356-1373.

Донская Т.В., Мазукабзов А.М. Геохимия и возраст пород нижних пластин Бутулийн-Нурского и Заганского комплксов метаморфических ядер (северная Монголия Западное Забайкалье) // Геодинамика и тектонофизика, 2014, т. 5 (3), с. 683-701.

Жданов А.В. и др. Геологическое доизучение масштаба 1:200000 и подготовка к изданию госгеолкарты-200 территории листа N-40-XVIII (Учалинская площадь). Отчет по темам № 608 и № 140. Книга 1(текст). Санкт-Петербург, 2003, 284 с.

Знаменский С.E. Структурные условия формирования коллизионных месторождений золота восточного склона Южного Урала. Уфа: «Гилем», 2009, 348 с.

Зинькова Е.А., Ферштатер Г.Б. Синплутонические дайки в гранитоидах Верхисетского массива (Средний Урал) // Литосфера, 2007, № 2. с. 141-151.

Иванов В.С. О влиянии температуры и химической активности калия на состав биотитов в гранитоидах (на примере Западно- и Восточно-Иультинского интрузивов Центральной Чукотки) // Изв. АН СССР. Сер. геол., 1970, № 7, с. 20-30.

Интерпретация геохимических данных: Учебное пособие. М: ИнтерметИнжиниринг, 2001. 288 с.

Каллистов Г.А., Осипова Т.А. Геология и геохимия синплутонических даек в Челябинском гранитном массиве (Южный Урал) // Geodynamics and Tectonophysics, 2017, v. 8, issue 2, p. 331-345.

Крук Н.Н. Континентальная кора Горного Алтая: этапы формирования и эволюции, индикаторная роль гранитоидов // Геология и геофизика, 2015, т. 56(8), с. 1403-1423.

Маракушев А.А., Безмен Н.И. Минералого-петрологические критерии рудоносности изверженных пород. М..: Наука, 1992, 316 с.

Мартынов Ю.А. Основы магматической геохимии. - Владивосток: Дальнаука, 2010, 228 c.

Мизенс Г.А. Седиментационные бассейны и геодинамические обстановки в позднем девоне - ранней перми Южного Урала. Екатеринбург: ИГГ УрО РАН, 2002, 190 с. 
Осипова Т.А., Каллистов Г.А., Баянова Т.Б. Возможные источники гранитоидных магм Челябинского плутона (ЮжныйУрал) по изотопным U-Pb, Rb-Sr, Sm-Nd данным // Изотопные системы и время геологических процессов. Материалы IV Росс. конф. по изотопной геохронологии. Т.II. Санкт-Петербург: ИП Каталкина, 2009, с. 68-71.

Попов В.С., Богатов В.И., Журавлев Д.З. Источники гранитных магм и формирование земной коры Среднего и Южного Урала: Sm-Nd и Rb-Sr изотопные данные // Петрология, 2002, т. 10 (4), с. 389-410.

Пучков В.Н. Геология Урала и Приуралья (актуальные вопросы стратиграфии, тектоники, геодинамики и металлогении). Уфа: ДизайнПолиграфСервис, 2010, 280 с.

Пучков В.Н. Плюм-зависимый гранит-риолитовый магматизм // Литосфера, 2018, 18 (5), с. 692-706.

Ронкин Ю.Л. Изотопы стронция - индикаторы эволюции магматизма Урала // Ежегодник-1988. Свердловск: ИГГ УНЦ АН СССР, 1989, с. 107-109.

Ронкин Ю.Л., Семенов И.В., Лепихина О.П., Попова О.Ю. Интрузивы Магнитогорской раннекаменноугольной рифтогенной структуры: Sr-Nd изотопные ограничения // Ежегодник - 2005 / Институт геологии и геохимии им. акад. А.Н. Заварицкого УрО РАН: Информационный сборник научных трудов. Екатеринбург: ИГГ УрО РАН, 2006, с. 314-318.

Салихов Д.Н., Бердников П.Г. Магматизм и оруденение позднего палеозоя Магнитогорского мегасинклинория. Уфа, 1985, 94 с.

Салихов Д.Н., Митрофанов В.А. Интрузивный магматизм верхнего девона нижнего карбона Магнитогорского мегасинклинория (Южный Урал). Уфа: УНЦ РАН, 1994, 142 с.

Салихов Д.Н., Мосейчук В.М., Холоднов В.В., Рахимов И.Р. Каменноугольный вулкано-интрузивный магматизм Магнитогорско-Богдановского грабена в свете новых геолого-геохимических данных // Литосфера, 2014, № 5, с. 33-55.

Салихов Д.Н., Холоднов В.В., Осипова Т.А., Рахимов И.Р. Магматизм и оруденение (карбон-пермь) в эволюции аккреционно-коллизионного складчатого пояса Южного Урала // Литосфера, 2016, № 5, с. 35-57.

Салихов Д.Н, Холоднов В.В., Пучков В.Н., Рахимов И.Р. Субдукция, коллизия и плюмы в эпоху позднепалеозойского магматизма Магнитогорской зоны Южного Урала // Литосфера, 2019, т. 19 (2), с. 191-208.

Серавкин И.Б., Знаменский С.Е., Косарев А.М. Разрывная тектоника и рудоносность Башкирского Зауралья. Уфа: Полиграфкомбинат, 2001. 318с.

Смирнов В.Н., Ронкин Ю.Л., Пучков В.Н., Солошенко Н.Г., Стрелецкая М.В. Новые данные о генезисе земной коры восточного сектора Среднего Урала: изотопные $\mathrm{Sr}-$ Nd ограничения // Доклады Академии Наук, 2016, т. 467 (5), с. 566-571.

Сурин Т.Н., Мосейчук В.М. Геодинамическое развитие Магнитогорского палеозойского пояса (Южный Урал) // Вестник Спб ГУ, 1995, сер. 7, вып. 4, № 28, с. 11-18.

Сурин T.Н., Мосейчук В.M. Магматизм Магнитогорско-Мугоджарской палеоостроводужной системы как результат проявления субдукционных процессов// Палеозоны субдукции: тектоника, магматизм, метаморфизм, седиментогенез. Тез. докл. Екатеринбург: УрО РАН, 1999, с. 145-147.

Тевелев А.В., Кошелева И.А., Попов В.С., Кузнецов И.Е., Осипова Т.А., Правикова Н.В., Вострецова Е.С., Густова А.С. Палеозоиды зоны сочленения 
Восточного Урала и Зауралья // Тр. Лаборатории геологии складчатых поясов. М., 2006. Вып. 4, 292 с.

Ферштатер Г.Б. Петрология главных интрузивных ассоциаций. М.: Наука, 1987. 263 c.

Ферштатер Г.Б. Палеозойский интрузивный магматизм Среднего и Южного Урала. Екатеринбург: РИО УрО РАН, 2013, 368 с.

Ферштатер Г.Б., Бородина Н.С., Беа Ф., Монтеро П. Модель мантийно-корового взаимодействия и сопряженного магматизма в надсубдукционном орогене (Палеозой Урала) / Литосфера, 2018, т. 18 (2), с. 177-207.

Ханчук А.И., Голозубов В.В., Мартынов Ю.А., Симаненко В.П. Раннемеловая и палеогеновая трансформные континентальные окраины (калифорнийский тип) Дальнего Востока России // Тектоника Азии. М., ГЕОС, 1997, с. 240-243.

Холоднов В.В., Бушляков И.Н. Галогены в эндогенном рудообразовании. Екатеринбург: УрО РАН, 2002, 392 с.

Холоднов В.В., Шагалов Е.С., Бородина Н.С. Гранитоидный магматизм северной части Магнитогорской мегазоны: петрогенезис, геохимическая и металлогеническая эволюция (Au, Mo, W и др.) // Вестник Уральского отд. Российского Минералогического общества, 2009, № 6, Науч. изд., Екатеринбург: ИГГ УрО РАН, с. 3-29.

Холоднов В.В., Шагалов Е.С., Коновалова Е.В., Замятин Д.А., Салихов Д.Н. Флюидные элементы-минерализаторы (галогены и сера) в эволюции состава и потенциальной рудоносности крупного Ахуново-Петропавловского ареала орогенного гранитоидного магматизма на севере Магнитогорской мегазоны // Ежегодник-2012. Труды Института геологии и геохимии им. ак. А.Н.Заварицкого УрО РАН. 2013, Вып. 160, Екатеринбург: ИГГ УрО РАН, с. 167-175.

Холоднов В.В., Салихов Д.Н., Шагалов Е.С., Коновалова Е.В., Рахимов И.Р. Роль галогенов и серы в апатитах при оценке потенциальной рудоносности позднепалеозойских габброидов Западно-Магнитогорской зоны (Ю. Урал) на Cu-Ni, Fe-Ti и Au оруденение // Минералогия, 2015, №3. с. 45-61.

Холоднов В.В., Крук Н.Н., Петров Г.А., Шагалов Е.С. Гранитоидный магматизм и рудоносность Урала и Горного Алтая как отражение особенностей формирования и эволюции континентальной коры. Корреляция алтаид и уралид: магматизм, метаморфизм, стратиграфия, геохронология, геодинамика и металлогения. // Материалы Третьей международной научной конференции. 2016, Новосибирск: Институт геологии и минералогии СО РАН, с. 198-200.

Холоднов В.В., Шагалов Е.С., Каллистов Г.А., Коновалова Е.В. Минералогические и геохимические признаки связи интрузивных и дайковых образований Ахуновского и Карагайского гранитных массивов (Южный Урал). // Ежегодник-2016, Труды Института геологии и геохимии им. акад. А.Н. Заварицкого УрО РАН, 2017а, Вып. 164. Екатеринбург: ИГГ УрО РАН, с. 183-190.

Холоднов В.В., Ферштатер Г.Б., Шагалов Е.С., Шардакова Г.Ю. Рифейский магматизм и рудообразование, предшествующие раскрытию Уральского палеоокеана (западный склон Южного Урала) // Литосфера, 2017б, № 2, с. 5-27.

Цыганков А.А., Хубанов В.Б., Травин А.В., Лепехина Е.Н., Бурмакина Г.Н., Анциферова Т.Н., Удоратина О.В. Позднепалеозойские габброиды Западного Забайкалья: U-Pb и Ar-Ar изотопный возраст, состав, петрогенезис // Геология и геофизика, 2016, т. 57 (5), с. 1005-1027. 
Шатагин К.Н., Астраханцев О.В., Дегтярев К.Е., Лучицкая М.В. Неоднородность континентальной коры восточного Урала: результаты изотопногеохимического изучения палеозойских гранитоидных комплексов // Геотектоника, 2000, № 5, с. 44-60.

Язева Р.Г., Бочкарев В.В. Геология и геодинамика Южного Урала (опыт геодинамического картирования). Екатеринбург.1998. 203с.

Ярмолюк В.В., Кузьмин М.И., Воронцов А.А. Конвергентные границы западнотихоокеанского типа и их роль в формировании Центрально-Азиатского складчатого пояса // Геология и геофизика, 2013, т. 54 (12), с. 1831-1850

Ярмолюк В.В., Козловский А.М., Саватенкова В.М. Изотопные (Nd, $\mathrm{Pb})$ источники Хангайского батолита: к проблеме формирования гигантских батолитов Центральной Азии // Корреляция алтаид и уралид: глубинное строение литосферы, стратиграфия, магматизм, метаморфизм, геодинамика и металлогения: Материалы Четвертой международной научной конференции. 2-6 апреля, 2018г., Новосибирск: Институт геологии и минералогии им. С.В.Соболева Со РАН. Новосибирск: Изд-во СО PAH, 2018, с. 179-181.

Abratis M. Geochemical variations in magmatic rocks from southern Costa Rica as a consequence of cocos ridge subduction and uplift of the Cordillera de Talamanca: Ph.D. thesis Göttingen University, 1998, 136 p.

Hammarstrom J.W., Zen E-an. Aluminum in hornblende: an empirical igneous geobarometr // Amer. mineralogy, 1986, v. 71, № 11-12, p. 1297-1313.

Henry D.J., Guidotti C.V., Thomson J.A. The Ti-saturation surface for low-to-medium pressure metapelitic biotites: Implications for geothermometry and Ti-substitution mechanisms // Am. Min., 2005. v. 90, p. 316-328.

Kepezhinskas P., McDermott F., Defant M.J., Hochstaedter A., Drummond M.S., Hawkesworth C.J., Koloskov A., Maury R.C., Bellon H. Trace element and Sr-Nd-Pb isotopic constraints on a three-component model of Kamchatka Arc petrogenesis // Geochimica et Cosmochimica Acta, 1997, v. 61, p. 577-600.

Le Bas M.J., Le Maitre R.W., Streckeisen A., Zanettin B. A chemical classification of volcanic rocks based on the total alkalisilica diagram // Journal of Petrology, 1986, v. 27, p. 745750 .

Otten M.T. The origin of brown hornblende in the Artfjallet gabbro and dolerites. // Contrib. Mineral. Petrol., 1984, v. 86, p. 189-99.

Pearce J.A. Role of the sub-continental lithosphere in magma genesis at acrive continental margins: p. 230-249 in, Hawkesworth, C.J. and Norry, M.J., eds., Continental Basalts and Mantle Xenoliths, Shiva Publishing Ltd., Cambridge, Mass. 1983, 272 p

Pearce J.A. Geochemical fingerprinting of oceanic basaltswith applications to ophiolite classification and to search forArchean oceanic crust // Lithos, 2008, 100, p. 14-43.

Pearce J.A., Harris N.W., Tindle A.G. Trace element discrimination diagrams for the tectonic interpretation of granitic rocks. // Journal of Petrology, 1984, v. 25, p. 956-983.

Schmidt M.W. Experimental calibration of the Al-in-hornblende geobarometer at $650 \mathrm{C}$, 3.5-13.0 kbar. Terra abstracts, 1991, v. 3, № 1, p. 30.

Sun S., McDonough W. F. Chemical and isotopic systematics of oceanic basalts: implications for mantle composition and processes. // Geological Society, London, 1989, v. 42, p. 313-345. 
Woodhead J.D., Hergt J.M., Davidson J.P., Eggins S.M. Hafnium isotope evidence for 'conservative'element mobility during subduction zone processes // Earth and Planetary Science Letters, 2001, v. 192, p. 331-346. 


\title{
ПОДРИСУНОЧНЫЕ ПОДПИСИ К СТАТЬЕ
}

\author{
В.В. Холоднов, Е.С. Шагалов, Г.А. Каллистов, Г.Ю. Шардакова, \\ Д.Н. Салихов, Е.В. Коновалова \\ «АХУНОВО-ПЕТРОПАВЛОВСКИЙ ГРАНИТОИДНЫЙ АРЕАЛ КАК ОКРАИННО- \\ КОНТИНЕНТАЛЬНЫЙ ЦЕНТР ДЛИТЕЛЬНОГО МАНТИЙНО-КОРОВОГО \\ ВЗАИМОДЕЙСТВИЯ: РОЛЬ СУБДУКЦИОННЫХ И \\ РИФТОГЕННО-ПЛЮМОВЫХ ИСТОЧНИКОВ»
}

Рис. 1. (а) Структурно-геологическая схема Южного Урала, по [Салихов и др., 2019a] с позицией Ахуново-Петропавловского гранитоидного ареала (оконтурен рамкой) и других гранитоидных интрузий и комплексов в Магнитогорской мегазоне (выделены цветом).

Условные обозначения: 1 - додевонские вулканогенно-осадочные образования, 2 вулканогенно-осадочные комплексы девона, 3 - вулканогенно-осадочные комплексы карбона, 4 -осадочные комплексы пермского возраста, 5 - гипербазиты, 6 - габброиды, 7 гранитоидные массивы Восточно-Уральской и других мегазон Ю. Урала, 8 - гранитоидные комплексы Магнитогорской мегазоны, 9 - тектонические границы (а - разделяющие мегазоны, б - предполагаемые, в - разделяющие подзоны). Римскими цифрами обозначены: I - Магнитогорская мегазона, II - Уйско-Новооренбургская сутура, III Восточно-Уральская мегазона, IV - Копейская сутура, V - Троицкая зона, VI Джетыгаринская зона, VII - Валерьяновская зона. Подзоны Магнитогорской мегазоны: А Западно-Магнитогорская (ЗМП), Б - Центрально-Магнитогорская (ЦМП), В - ВосточноМагнитогорская (ВМП);

(б) - Гранитоидные ареалы на севере Магнитогорской мегазоны. Условные обозначения: I - окраина Восточно-Европейской платформы; II - Зона Главного Уральского разлома (ГУР); III - Магнитогорская мегазона; IV - зона сочленения Магнитогорской мегазоны с Восточно-Уральским (V) поднятием. Массивы гранитоидов: 1 - Атлянский и Тележинский, 2 - Чашковский, 3 - мелкие интрузии и дайки балбукского комплекса, 4 - Уйский, 5 - Вандышевский, 6-10 интрузии в составе АхуновоПетропавловского гранитоидного ареала (6 - Воронинский массив, 7 - Уйскоборский, 8 Петропавловский, 9 - Ахуновский, 10 - Карагайский), 11 - 16 интрузии в составе Верхнеуральско-Кассельского гранитоидного ареала (11-Краснинский массив, 12 Нижегородский, 13 - Заматохинский, 14 - Верхнеуральский, 15 - Кассельский, 16 Погорельский), 17 - Рассыпнянский массив, 18 - Магнитогорская группа рифтогенных габбро-гранитных интрузий.

Рис. 2. Диаграммы $\left(\mathrm{Na}_{2} \mathrm{O}+\mathrm{K}_{2} \mathrm{O}\right)-\mathrm{SiO}_{2}$ и $\mathrm{Al} /(\mathrm{Ca}+\mathrm{Na}+\mathrm{K})-\mathrm{Al} /(\mathrm{Na}+\mathrm{K})$ для гранитоидных интрузий Ахуново-Петропавловского ареала. Условные обозначения: 1 породы Петропавловского массива; 2 - породы Ахуновского массива; 3 - породы Карагайского массива; 4 - граниты Уйскоборского массива.

Рис. 3. Петрохимические особенности основных типов пород гранитоидных интрузий Ахуново-Петропавловского ареала. Условные обозначения: 1 - 2 - породы Петропавловского массива (1 - основные интрузивные фазы, 2 - дайковая серия); 3 - 4 породы Ахуновского массива (3 - основная интрузивная фаза, 4 - дайковая серия); 5 - 6 - 
породы Карагайского массива (5 - основная интрузтвная фаза, 6 - дайковая серия); 7 граниты Уйскоборского массива.

Рис. 4. Распределение микроэлементов в породах гранитоидных интрузий АхуновоПетропавловского ареала. Условные обозначения приведены на рис. 4.

Рис. 5. Графики нормированных на хондрит содержаний Р3Э (a, б) и спайдерграммы содержаний микроэлементов в гранитоидах Ахуново-Петропавловского ареала нормированных на состав БСОХ (в, г) по [Sun, McDonough, 1989]. Условные обозначения: 1 - интрузивные породы Петропавловского; 2 - Карагайского; 3 Ахуновского и 4 - Уйскоборского массивов.

Рис. 6. Дискриминационные диаграммы для интрузий Ахуново-Петропавловского гранитоидного ареала. Поля составов гранитоидов различных геодинамических обстановок по [Pearce et al., 1984]: syn-COLG - синколлизионных, VAG - островодужных (надсубдукционных), WPG - внутриплитных, ORG - гранитов срединно-океанических хребтов. Условные обозначения приведены на рис. 3.

Рис. 7. Диаграммы, характеризующие вклад различных источников вещества [Pearce, 1983; Kepezhinskas et al., 1997; Abratis, 1998; Woodhead et al., 2001; Мартынов, 2010; Волынец и др., 2018] в петрогенезис гранитоидных интрузий АхуновоПетропавловского ареала. Условные обозначения: 1 - породы Петропавловского массива; 2 -породы Ахуновского массива; 3 - 4 - породы Карагайского массива (3 - основная интрузтвная фаза, 4 - дайковая серия); 5 - граниты Уйскоборского массива.

Рис. 8. Диаграммы Nb/Yb - Th/Yb (а) и $\mathrm{Zr} / \mathrm{Y}$ - Nb/Y (б) по [Pearce, 2008], характеризующие особенности состава вулкано-интрузивных образований Магнитогорско-Богдановского грабена (МБГ), габброидов и диоритов Петропавловского массива, а также подобных по составу пород ряда мантийно-коровых батолитов ГТГГ типа, их возможную связь с различными мантийными и коровыми магматическими и флюидными источниками. Условные обозначения: 1 - базальты греховской и березовской свит, 2 - габброиды куйбасовского и богдановского комплексов МБГ, 3 - габброиды Петропавловского массива ВМП, 4 - 6 габбро и диориты батолитов ГТГГ (Верхисетский (4), Челябинский (5), Сыростанский массивы (6)). ОIВ - компонент базальтов океанических островов; N-MORB - компонент нормальных срединно-океанических базальтов; E-MORB, EN - обогащенный компонент срединно-океанических базальтов; REC - рециклированный мантийный компонент; PM - компонент примитивной мантии; DM - слабо деплетированный мантийный компонент; DEP - глубоко деплетированный мантийный компонент; BKК - верхняя континентальная кора; HKK - нижняя континентальная кора.

Рис. 9. Диаграммы $\varepsilon \mathrm{Nd}$ - возраст (а) и $\varepsilon \mathrm{Nd}-{ }^{87} \mathrm{Sr} /{ }^{86} \mathrm{Sr}_{0}$ (б) для интрузий АхуновоПетропавловского гранитоидного ареала. Черной узкой стрелкой показана эволюция изотопного состава в породах Ахуново-Петропавловского ареала (от Петропавловского массива к Уйскоборскому). Условные обозначения: 1 - породы Петропавловского массива; 2 - породы Ахуновского массива; 3 - породы Карагайского массива; 4 - граниты Уйскоборского массива.

Большое поле со стрелкой вниз (рис. 9а) характеризует эволюцию $\mathrm{Nd}$ в диапазоне возрастов 420-250 млн лет в надсубдукционных и коллизионных интрузивных комплексах Среднего и Южного Урала в процессе закрытия Уральского палеоокеана и формирования зрелой континентальной коры Уральского орогена [Холоднов и др., 2017б]. Поля на рис. 9 выделены по данным [Богатов и др., 2000; Ронкин, 1989; Шатагин и др., 2000; Попов и др., 
2002; Тевелев и др., 2006; Осипова и др., 2009; Ронкин и др., 2006; Смирнов и др., 2016]. Поля: 5 - породы Магнитогорской группы массивов (М); 6 - габбро, диориты ВерхИсетского массива (ВИ); 7 - породы Челябинского массива (Ч); 8 - породы СыростанскоТургоякской группы массивов (С-Т); 9 - граниты Джабыкского комплекса (ДЖ); 10 граниты ватихского комплекса (Мурзинский массив) - рис. 9а; 11 - породы Верхнеуральского массива (ВУ). 


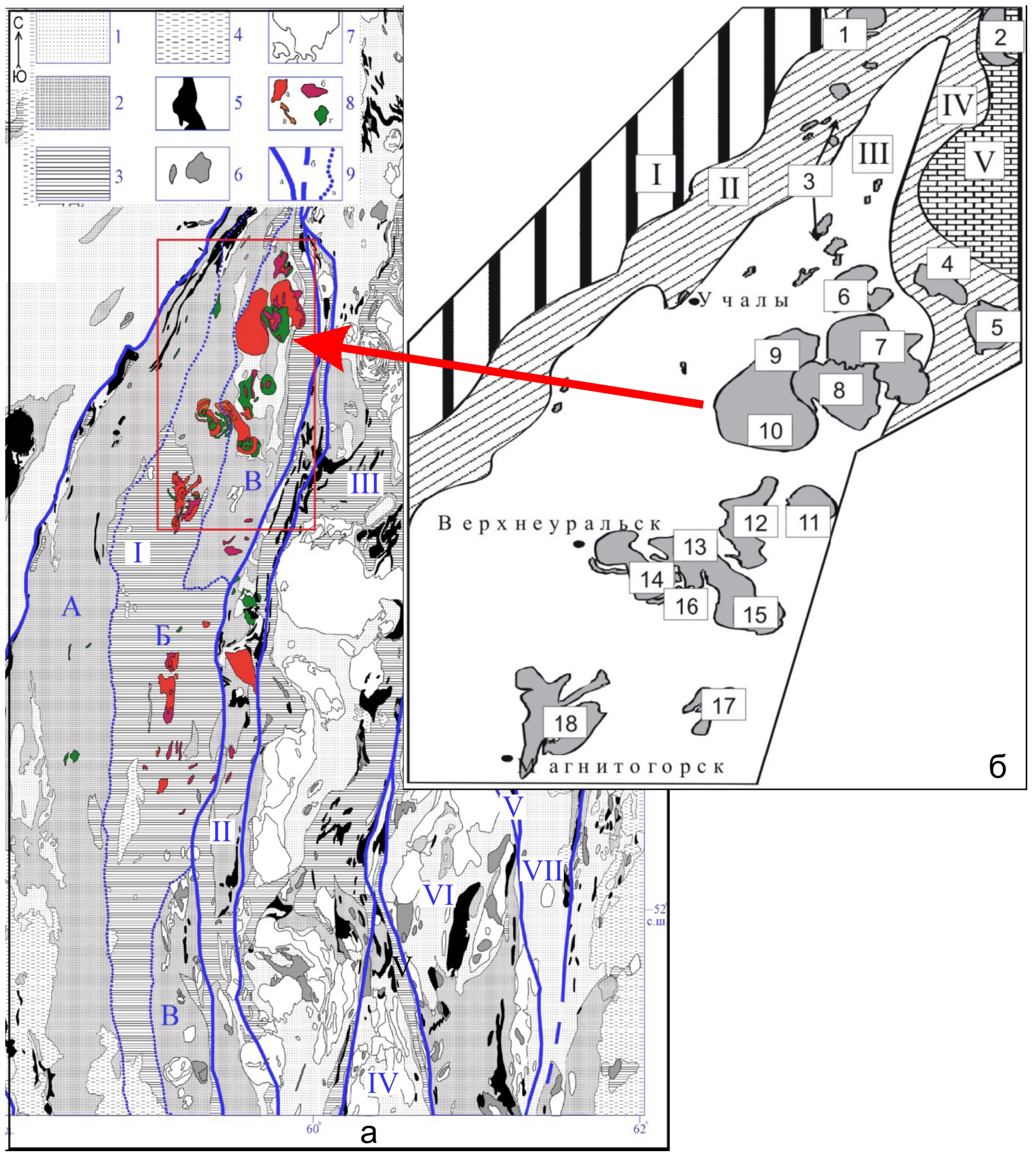



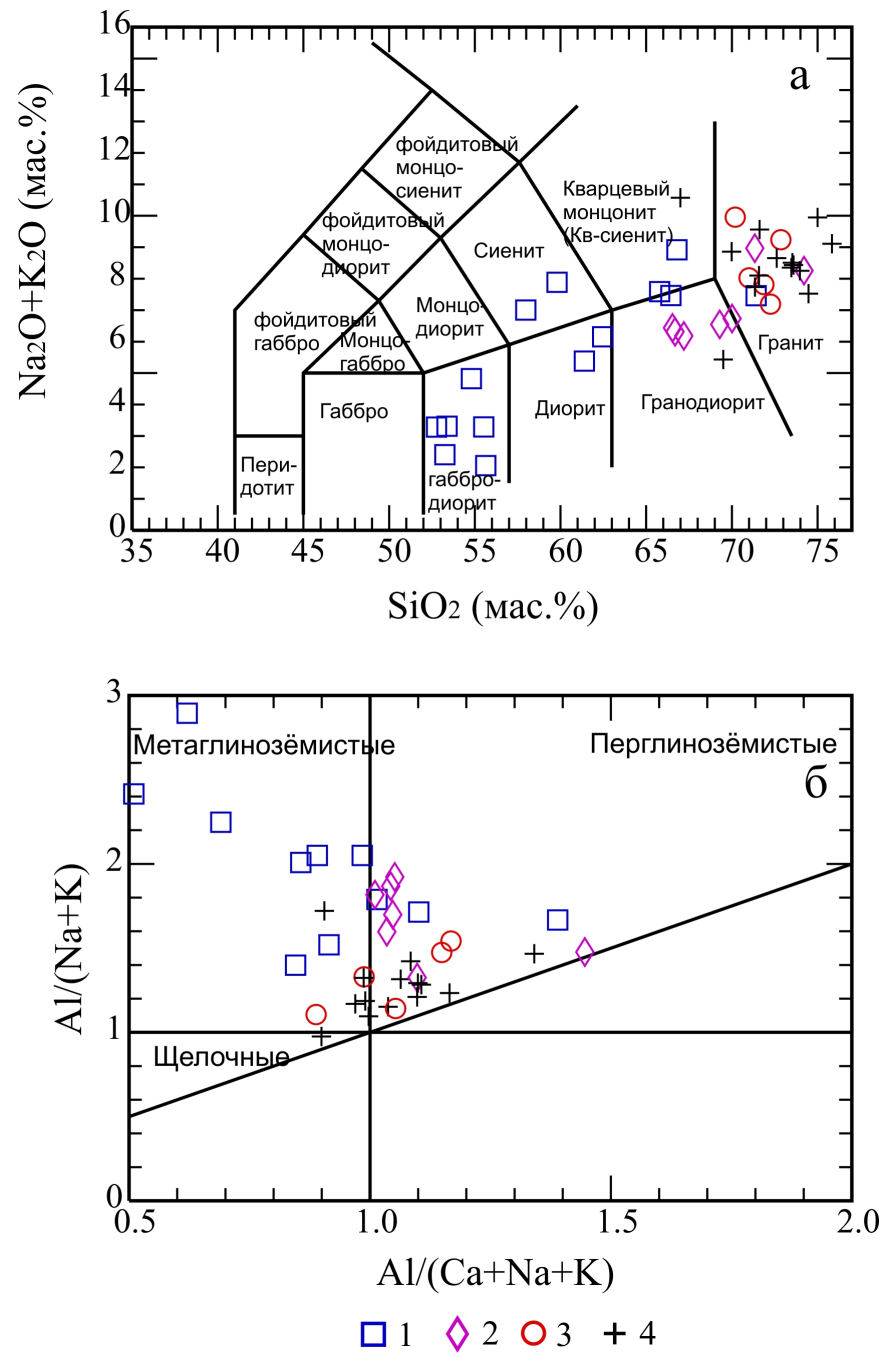

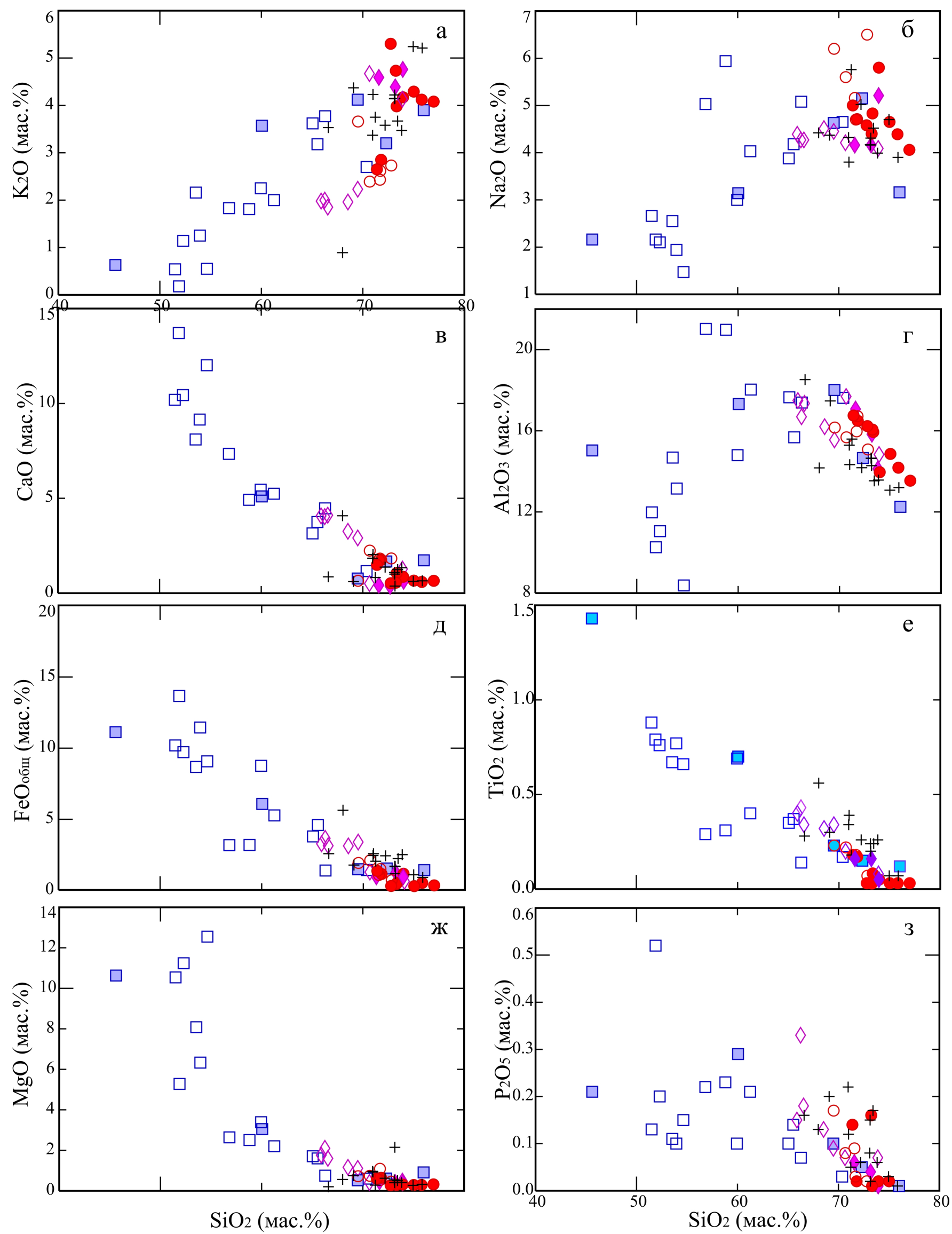

$\square 1 \square 2 \diamond 3 \diamond 4 \bigcirc 5 \bigcirc 6+7$ 

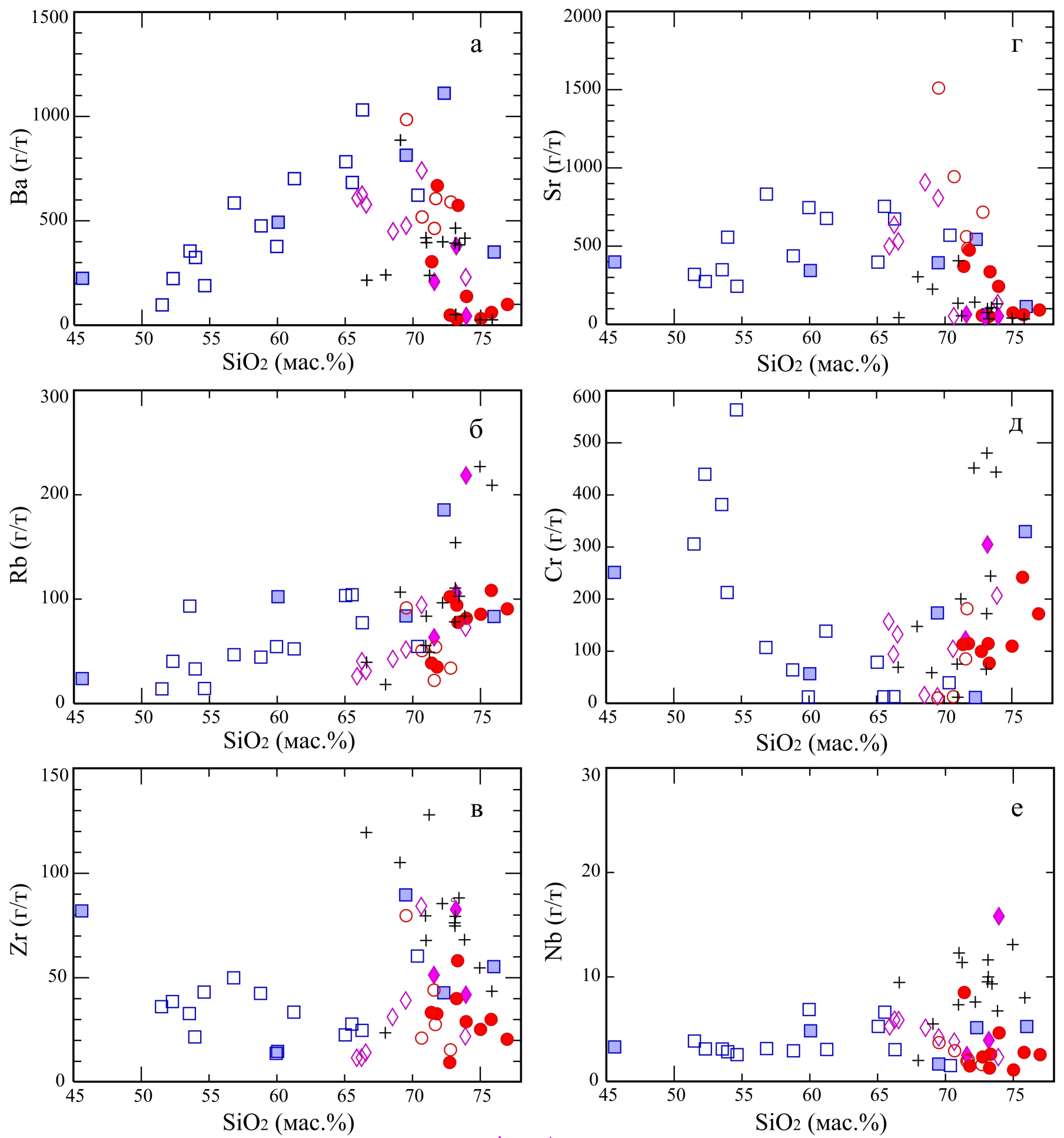

$\square 1 \square 2 \diamond 3 \diamond 4 \bigcirc 5 \bigcirc 6+7$ 

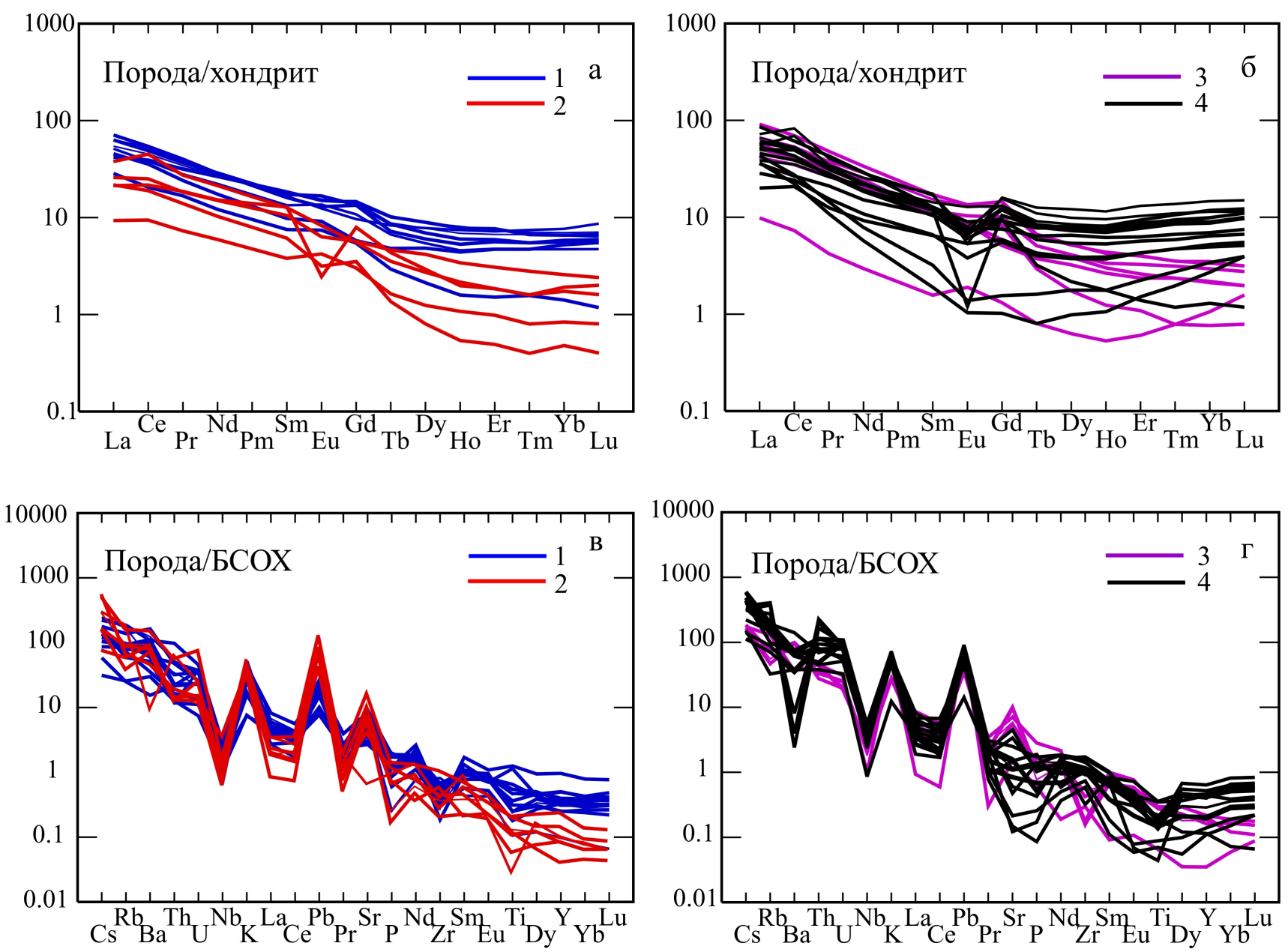

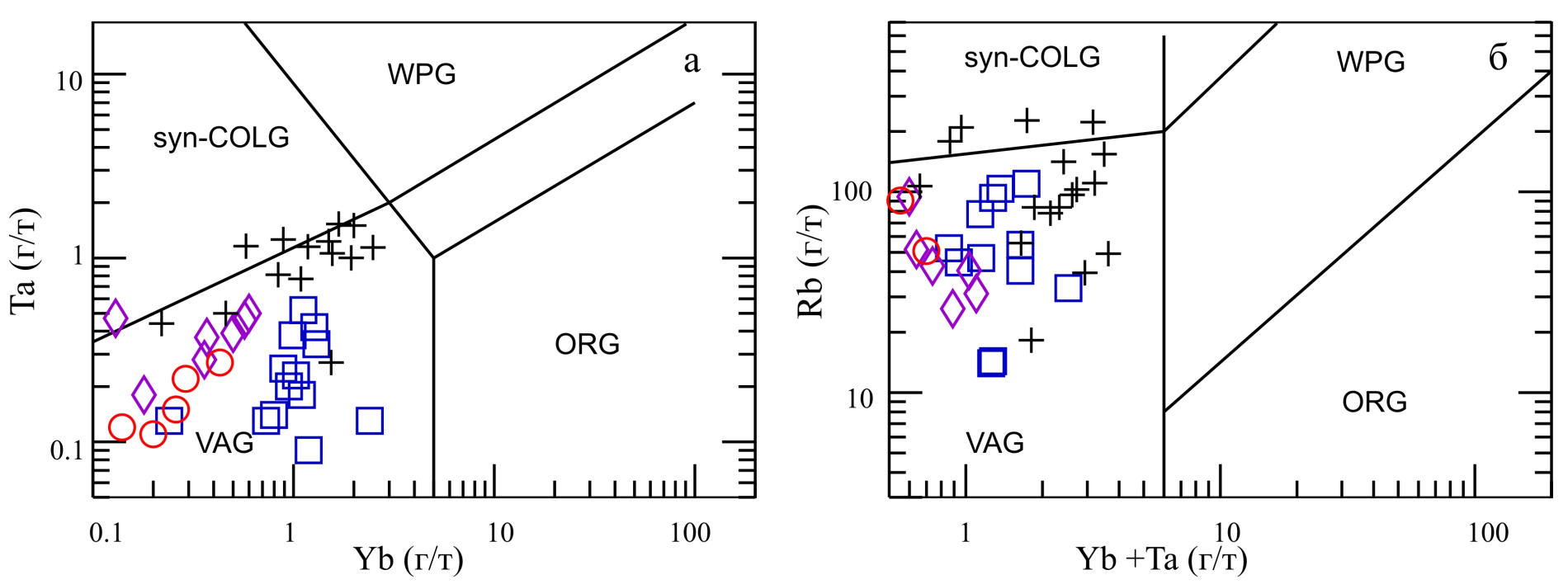

$\square 1 \diamond 2 \bigcirc 3+4$ 

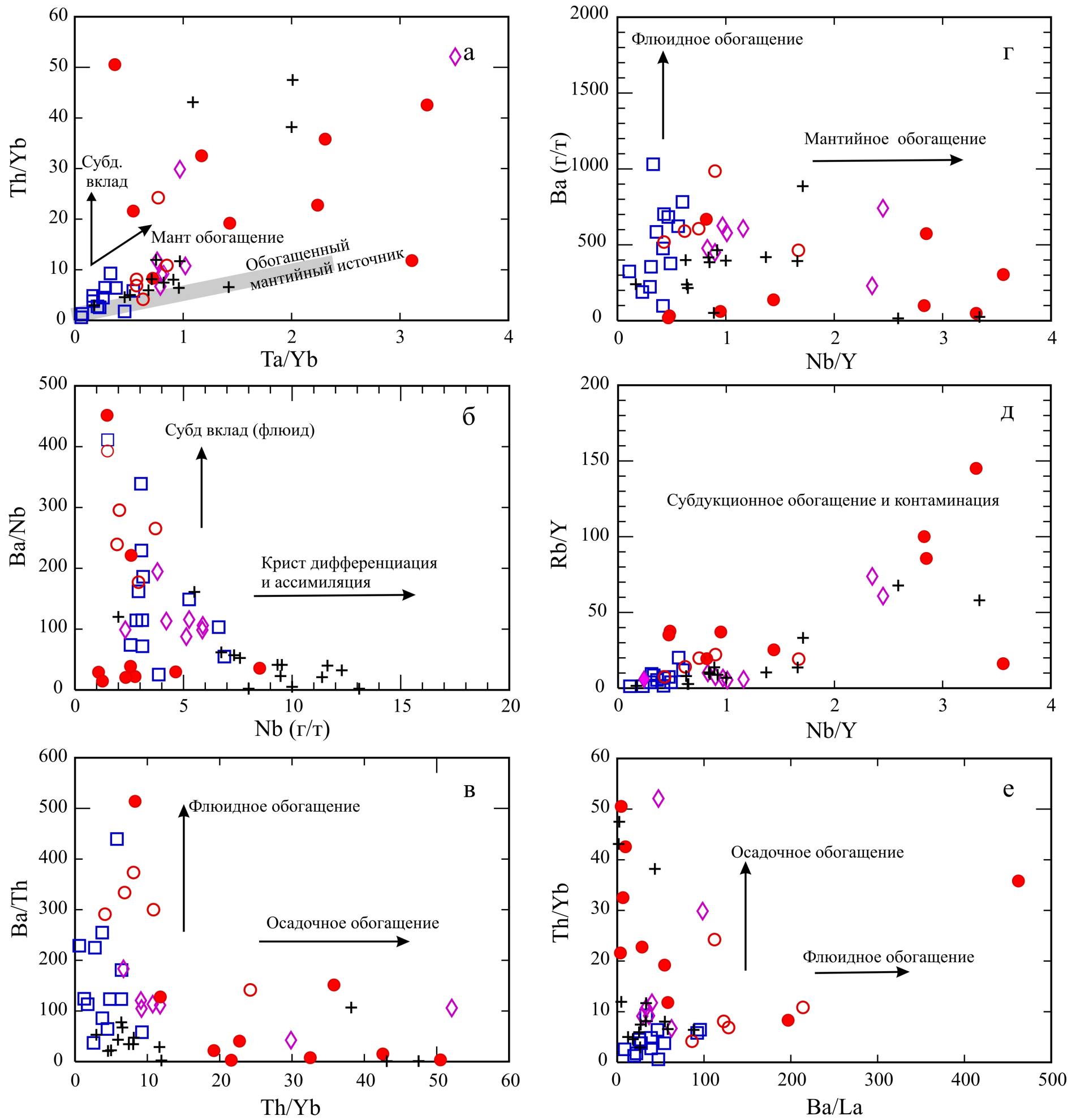

$\square 1 \diamond 2 \bigcirc 3 \bigcirc 4+5$ 

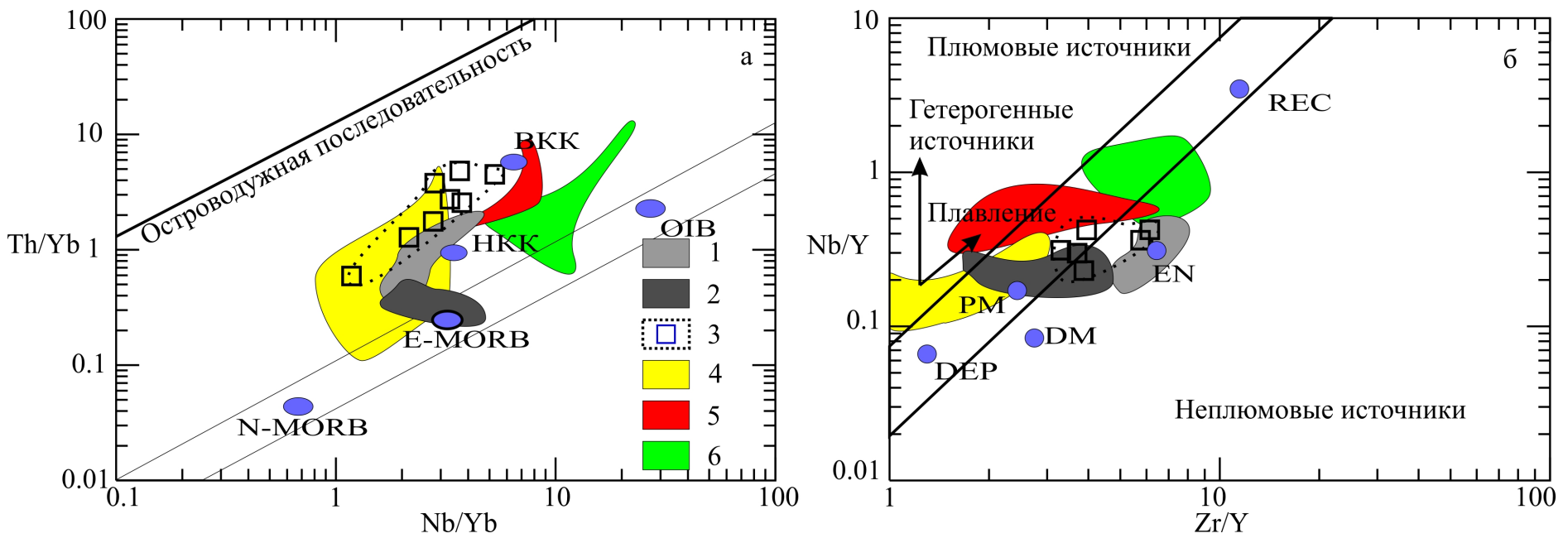

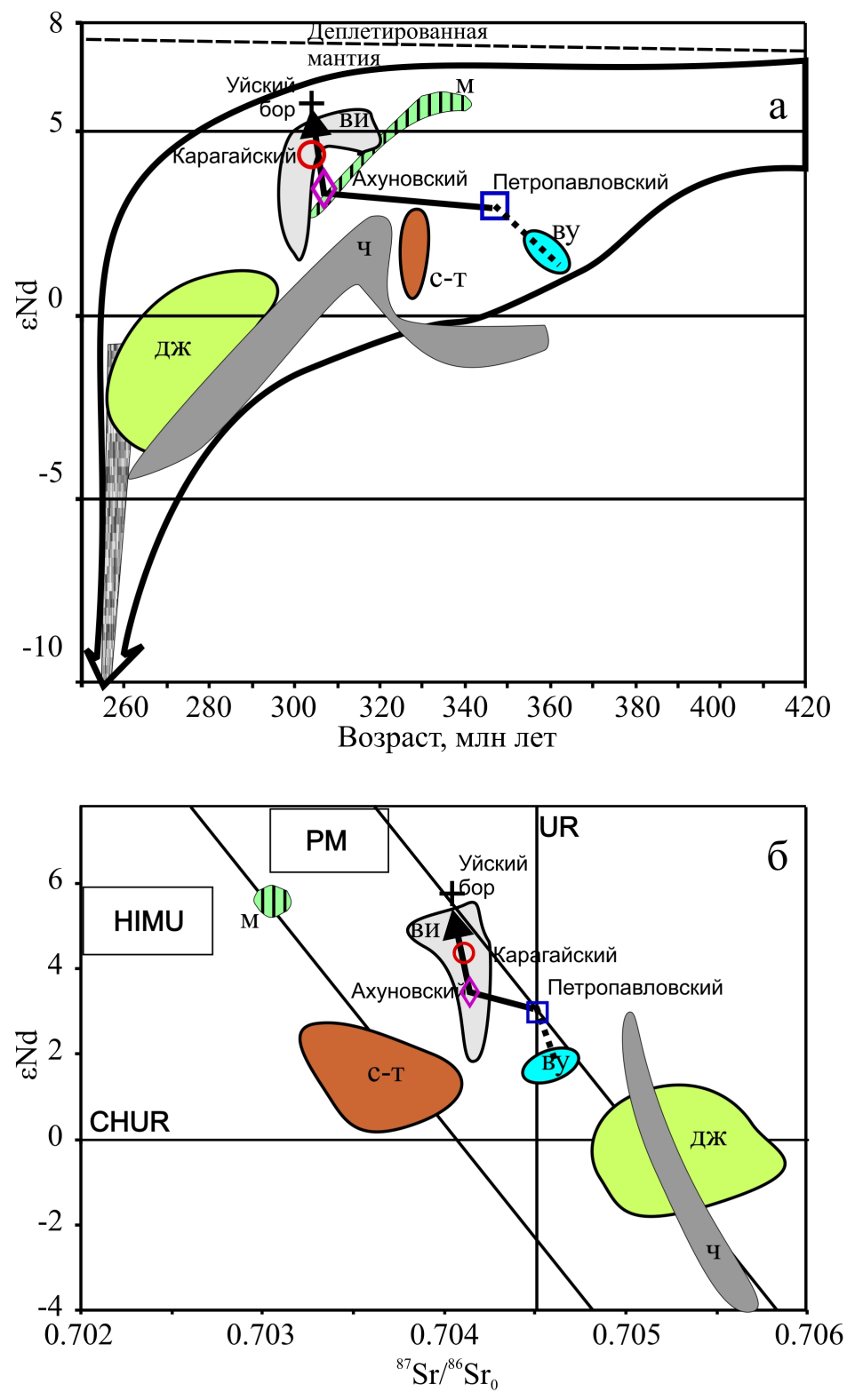

$\square 1 \diamond 203+4$

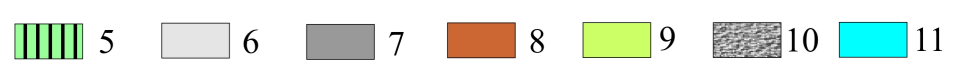

